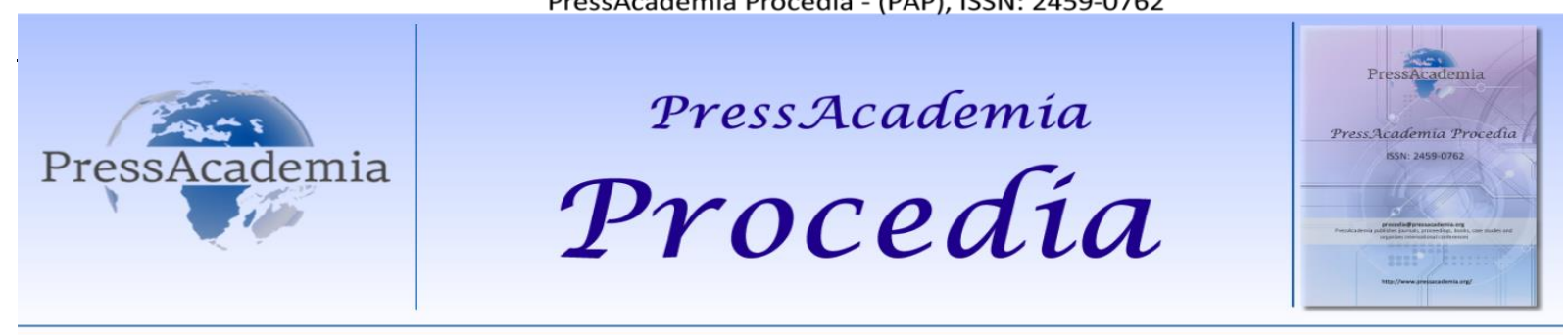

Global Business Research Congress (GBRC), May 24-25, 2017, Istanbul, Turkey.

\title{
DEVELOPMENT OF E-COMMERCE IN WORLD AND TURKEY AND THE IMPACTS OF MARKETING STRATEGIES IN E-COMMERCE ON TURKEY'S ECONOMY
}

\author{
DOI: 10.17261/Pressacademia.2017.675 \\ PAP-GBRC-V.3-2017(102)-p.925-945 \\ Nuray Terzi ${ }^{1}$, Cemre Gokce ${ }^{2}$ \\ ${ }^{1}$ Marmara University, Faculty of economics, Kuyubaşı, Goztepe, Istanbul, Turkey. nurayterzi@marmara.edu.tr \\ ${ }^{2}$ Marmara University, Social Sicences Institute, Goztepe, Istanbul, Turkey. cemregokce@hotmail.com.tr
}

\section{To cite this document}

Terzi, N. and C. Gokce, (2017), Development of e-commerce in world and Turkey and the impacts of marketing strategies in e-commerce on Turkey's economy. PressAcademia Procedia (PAP), V.3, p.925-945.

Permemant link to this document: http://doi.org/10.17261/Pressacademia.2017.675

Copyright: Published by PressAcademia and limited licenced re-use rights only.

\begin{abstract}
The aim of this study is to investigate the development of e-commerce and the impact of marketing strategies in e-commerce on economy. Economic indicators is used and and questionnaire method is applied to analyze the development of e-commerce and the impact of marketing strategies in e-commerce on economy. Results show that e-commerce is gaining a momentum in the world and Turkey as well, and e-marketing strategies are positively related on economy, both macroeconomic and microeconomic. E-commerce has lead to economic growth, facilitating trade and providing job creation in many countries. E-commerce in Turkey has also developed since 1990's and Turkey 's economy takes an advantage of e-commerce. Therefore, there should be more policies that will e-commerce in Turkey to reach high level growth rates and employment. Additonally, marketing strategies will be important for e-commerce inclusion. These strategies bring new opportunities to both producers and consumers. Therefore, e-marketing strategies should be widespread to whole economy.
\end{abstract}

Keywords: e-commerce, new economy, marketing, virtual marketing strategies, Turkey's economy

JEL Codes: M31, L81, O10

\section{DÜNYA'DA VE TÜRKIYE'DE E-TiCARETIN GELIŞiMi VE E-TiCARETTE PAZARLAMA STRATEJiLERININ TÜRKIYE EKONOMISINE ETKISI}

\section{ÖZET}

Bu çalışmanın amacı e-ticaretin gelişimini ve e-ticarette kullanılan pazarlama stratejilerinin ekonomi üzerindeki etkilerini incelemektir. E-ticaretin gelişimini ve pazarlama stratejilerinin etkisini ortaya koyabilmek için ekonomik göstergelerden yararlanılmış ve anket yöntemi uygulanmıştır. Sonuçlar e-ticaretin dünyada ve Türkiye'de önemli bir ivme kazandığını ve pazarlama stratejilerinin hem makroekonomik hem de mikroekonomik açıdan ekonomi üzerinde pozitif bir etkide bulunduğunu göstermektedir. E-ticaret, ticareti kolaylaştırarak ve iş yaratarak ekonomik büyümeye yol açmaktadır. Türkiye'de e-ticaret 1990'lı yıllardan bu yana gelişmekte ve Türkiye ekonomisi e-ticaretin avantajını almaktadır. Bu nedenle, daha yüksek büyüme ve istihdam seviyesine ulaşmak için daha fazla e-ticaret politikalarına ihtiyaç vardır. Ayrıca, pazarlama stratejileri e-ticaret kapsayıcılığı için önemli olacaktır. Sanal pazarlama stratejileri hem üreticilere hem de tüketicilere yeni fırsatlar sunmaktadır. Bu nedenle e-ticaret stratejileri ekonomi genelinde yaygınlaştırılmalıdır.

Anahtar Kelimeler: e-ticaret, yeni ekonomi, pazarlama, sanal pazarlama stratejileri, Türkiye ekonomisi JEL Kodları: M31, L81, O10 


\section{GíRiş}

1990'lı yıllardan itibaren bilgi ve iletişim teknolojileri alanında meydana gelen büyük değişimler ve internetin yaygınlaşmasıyla birlikte; zaman ve mekan kavramlarından bağımsız olarak çevrimiçi ağlar üzerinden iletişim kurabilmek mümkün hale gelmiş, başta ekonominin geleneksel yapısı olmak üzere, toplumları oluşturan sosyal ve kültürel dinamiklerde köklü değiş̧imler gözlenmiştir. Bu değişimler doğrultusunda, internetin üretici, satıcı, aracı ve tüketicilere sunduğu imkanlar, ticari faaliyetlerin gerçekleşme biçimini de etkilemiş böylece "elektronik ticaret" kavramı ortaya çıkmıştır. Ürün ve hizmetlere ilişkin dağıtım, reklam ve satışların telekomünikasyon ağları üzerinden gerçekleştirilmesini ifade eden elektronik ticaret, günümüzde ülkelerin ekonomik yapılarını ve refah düzeylerini etkileyen bir olgu olarak görülmektedir.

Mevcut teknolojik gelişimler, sadece bilgiye ulaşma yollarını değil, aynı zamanda bireylerle, kurumlarla olan karşııklı iletişim biçimini de etkilemektedir. Dijital teknolojiler, ürün ve hizmetlerin seçilmesi, satınalınmasını değiştirmektedir. Veri tüketim biçimi, verilerin devamlı genişleyen online nüfus tarafından yaratılan muazzam hacmi ve taşınabilir erişime doğru artan talep, oyunun kurallarını öngörülemez biçimde değiştirmektedir. Dünyanın daha çok köşesindeki daha çok insanın daha fazla videoya, daha zengin içeriğe, daha hızlı erişmesi işin doğasını değiştirmekte ve dijital pazarlama rekabete girmek isteyen herhangi bir girişim veya birey için ön koşul haline gelmektedir.

Bu çalışma e-ticaretin gelişimi ve e-ticarette pazarlama stratejilerinin ekonomiye etkilerini incelemeyi amaçlamaktadır. Bu amaçla; öncelikle e-ticaretin dünyada ve Türkiye'de gelişimi, e- ticarette kullanılan pazarlama stratejilerine yer verilecek sonrada e-ticarette kullanılan pazarlama stratejilerinin ekonomi üzerindeki etkileri üreticiler ve tüketiciler açısından ele alınarak, Türkiye ekonomisinin e-ticaret aracılığıyla gerçekleşen olumlu edinimleri üzerinde durulacaktır. Son bölümde ise; değerlendirmelere ve önerilere yer verilecektir.

\section{LITERATÜR INCELEMESI}

\subsection{DÜNYADA VE TÜRKIYE'DE E-TICARET}

Elektronik ticaret; farkı kurumlar ve kişilerce değişik boyutlarıyla ele alınan, dolayısıyla birbirinden farklı çok fazla tanıma sahip bir kavramdır. Bilgi ve iletişim teknolojilerindeki hızlı ve radikal değişimler, farklılaşan tüketici beklentileri ve bu doğrultuda çeşitlenen ürün ve hizmetler, e-ticaret'in tanım ve kapsamının her geçen gün genişlemesi ve çeşitlenmesi sonucunu doğurmaktadır.

Geleneksel anlamda ticaret; bir hizmet veya malın kar amaçlı olarak ekonomik değer taşıyan başka nesnelerle değişimini ifade ederken, elektronik ticaret; taraflar arasındaki bu değişim, yönetim ve tüketim faaliyetlerini etkileyen süreçlerin ve iş bilgilerinin elektronik araçlar üzerinden paylaşılması olarak tanımlanmaktadır. İktisadi İşbirliği ve Kalkınma Teşkilatı (OECD) tarafından yapılan tanımlamaya göre ise e-ticaret; işletmeler, bireyler, ülkeler, kamu veya özel kuruluşlar arasında mal veya hizmet satın alma veya satma işlemlerinin herhangi bir bilgisayar temelli ağ ile yapılması olarak ifade edilmektedir (OECD, 2016).

Avrupa Birliği'nin yasama ve yürütme organı olan Avrupa Komisyonu tarafından 1997 yılında yapılmış tanımlamaya göre ise "elektronik ticaret, işletme faaliyetlerinin elektronik ortamda gerçekleştirilmesi işlemidir. Bu faaliyetler metin, ses ve video verilerinin elektronik olarak iş lenmesi ve aktarımıyla oluşmakta ve üç ana başlık altında toplanmaktadır. Bunlar; ağlar üzerinden tüketiciye sunulan fiziksel ürünler, finans, bilgi ve hukuk gibi alanlarda verilen hizmetler ve sağlık, eğitim gibi geleneksel faaliyetlerdir (Canpolat, 2001). 2014 yılında Türkiye'de yürürlüğe giren "Elektronik Ti careti n Düzenlenmesi Hakkında Kanun" kapsamında: "Fiziki olarak karşı karşıya gelmeksizin, elektronik ortamda gerç ekleştirilen çevrim iç iktisadi ve ticari her tülü faaliyet" olarak ifade edilmiştir (www.mevzuat.gov.tr). Tanımlardan da anlaşılacağı gibi e-ticaret; mal ve hizmetlere dair üretim, pazarlama, alış, satış, sigorta, dağıtım ve ödeme işlemlerinin bilgisayar ağları üzerinden yürütülmesine imkan veren süreçleri kapsamaktadır. E-ticaret'in gelişimi, 1990'lı yıllarda internet teknolojilerinde görülen devrim boyutundaki ilerlemelerden etkilenmiştir. Bu tarihten önce e-ticaret faaliyetlerinin gerçekleştiğini söylemek mümkün olsa da; internet kullanımının sınırlı olması nedeniyle bugünkü kapsamıyla e-ticaretten bahsetmemiz mümkün değildi(Saatçioğlu, 2005) . İnternetin kullanımı önündeki kısıtlamaların kalktığı 1991 yılı ise e-ticaretin ilerlemesi açısından oldukça önemli bir dönüm noktası kabul edilmektedir. Bu tarihten günümüze kadar hızla artan internet kullanım oranları, bilgi ve iletişim teknolojilerine erişilebilirliğin kolaylaşması, 2000'li yılların sonuna doğru hayatlarımıza giren sosyal medya platform ve araçları e-ticaret'in gelişimini hız kesmeden devam ettirebilmesine olanak sağlamıştır. Eticaret'in gelişmesindeki en önemli unsur olmasına karşın, tek itici güç elbette teknoloji gelişimi ve kullanımında meydana gelen değişimler değildir. Bu değişimlerin öncülük ettiği; sosyal, kültürel ve siyasi alanda gerçekleşen dönüşüm ve yenilikler de e-ticaret'in mevcut kapsam ve boyutlarına ulaşmasında rol sahibi olmuştur.

Dünya ekonomisi küreselleşme ile birlikte yeni bir döneme girmiştir. Küreselleşme, sermaye hareketlerinin dünya geneline yayılması, ülkeler arası gelişen yoğun ilişkiler sonucu ekonomik, sosyal ve siyasi entegrasyonu meydana getirmesidir. Ekonomik ve ticari yönüyle ise; mal ve hizmetlerin serbest dolaşımındaki kısıtlamaların ortadan kaldırılarak 
dünyanın ortak bir pazar haline geldiği çok boyutlu bir süreci ifade etmektedir (Seyrek, 2002). Bilgi ve iletişim teknolojilerinin altın çağını yaşadığı günümüzde küreselleşmenin sosyal, ekonomik, siyasi ve kültürel bütün unsurları ağ kavramından etkilenmekte, bu etkileşimin sonucu olarak e-ticaret yapısı gereği küresel ve dünya ekonomilerini birleştirici bir olgu olarak öne çıkmaktadır. E- ticaret; küreselleşmenin yarattığı dinamiklerden beslenmekle birlikte; ayrıca ekonomi ve kültür alanında pazarlar arası etkileşimi ve dünya ticaret hacmini arttırmaktadır (Kazgan, 2002).

Dünya genelinde e-ticaret hacminde önemli artışlar gözlenmektedir. Amerika, Çin, Japonya ve İngiltere, Almanya gibi gelişmiş ülkelerde geleneksel sektörlerde meydana gelen e-dönüşümler, hızla büyüyen internet girişimleri ve e-ticareti hem hukuksal hem pratik anlamda destekleyen devlet politikalarının varlığı bu artışta büyük rol sahibidir. Bilgi ve iletişim teknolojilerindeki gelişmeler, tüketicilerin sanal alımlara artan ilgisi, internete erişiminin kırsal alanları da kapsayacak şekilde yaygınlaşması gibi unsurlar; bu artışın yükselen bir ivmeyle devam edeceğini ortaya çıkarmaktadır (Ekin, 1998). Internet kullanıcı sayısındaki artışlar, e-ticaretin giderek toplam ticaret üzerinde daha fazla etkili olacağına işaret etmektedir. Aşağıda 2014 yılında itibaren itibaren dünya genelinde internet kullanıcı sayısında gözlemlenen artış yer almaktadır. Internet kullanıcı sayısının 2020'ye kadar dünya nüfusunun yarısından fazlasını aşacağını göstermektedir. internetin yaygınlaşması ile birlikte online harcamalarda artacaktır.

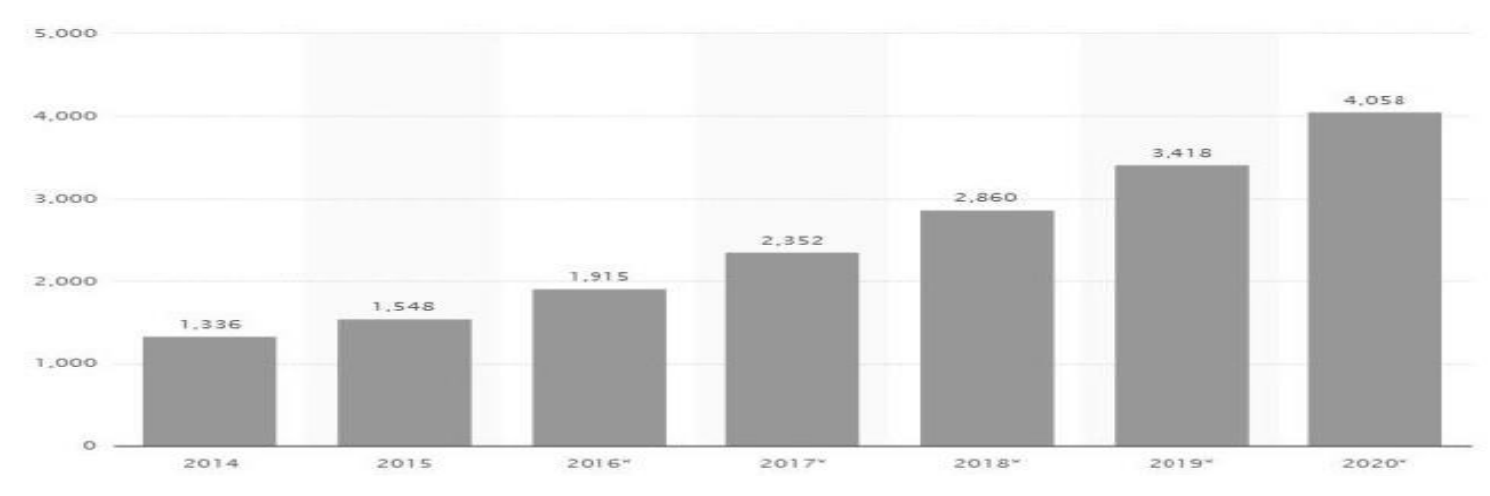

\section{Grafik 1: Internet Kullanıcı Sayısı}

Kaynak: https://www.statista.com/statistics/265147/number-of-worldwide-internet-users-by-region/

Grafik 2'den görüleceği gibi gelişmekte olan ülkelerin yoğun olarak yer aldığı Asya'da kullanıcı sayısı hızla artmaktadır ve Afrika'da gözlemlenen internet kullanıcı sayısındaki artışlar da oldukça umut vericidir.

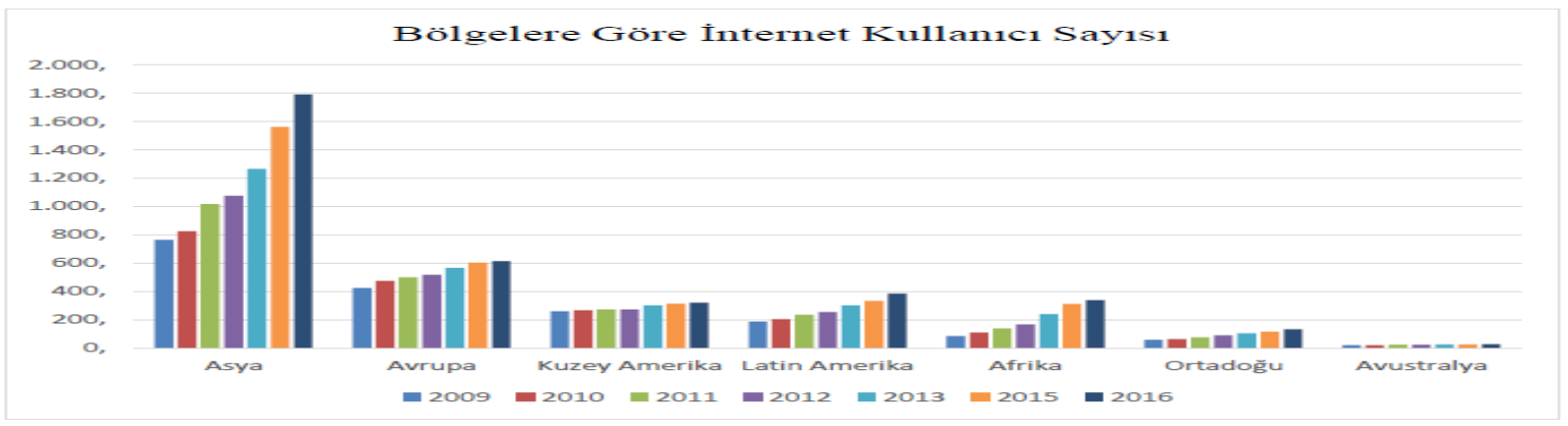

Grafik 2. Bölgelere Göre İnternet Kullanıcı Sayısı

Kaynak: https://www.statista.com/statistics/265147/number-of-worldwide-internet-users-by-region/

İnternet kullanıc sayısında yaşanan artışlar, e-ticaret satışlarına ve tüketicilerin çevrimiçi alışveriş alışkanlığı kazanmasına hem küresel hem bölgesel bazda katkı sağlayarak e-ticaret ekosisteminin gelişmesinin önünün 
açmıştır. 2015 yılı itibariyle, dünya genelinde 12 milyonu aşkın sanal mağaza bulunmaktadır. E-marketer'in yayınladığı rapora göre ise 2015 yılında, dünya genelinde perakende e-ticaret satışlarının hacmi 1.548 trilyon dolardır. Aynı rapora göre; e-ticaret satışlarının toplam perakende satışları içerisindeki oranı \%7.4 olarak belirtilmektedir. 2020 yılına gelindiğinde ise büyüyen e-ticaret hacmiyle birlikte bu oranın da artarak \%14.6'ya ulaşması beklenmektedir. Toplam global perakende e-ticaret satışı içerisinde; en yüksek payı alan ülkeler ise Çin ve ABD'dir (Grafik 3).

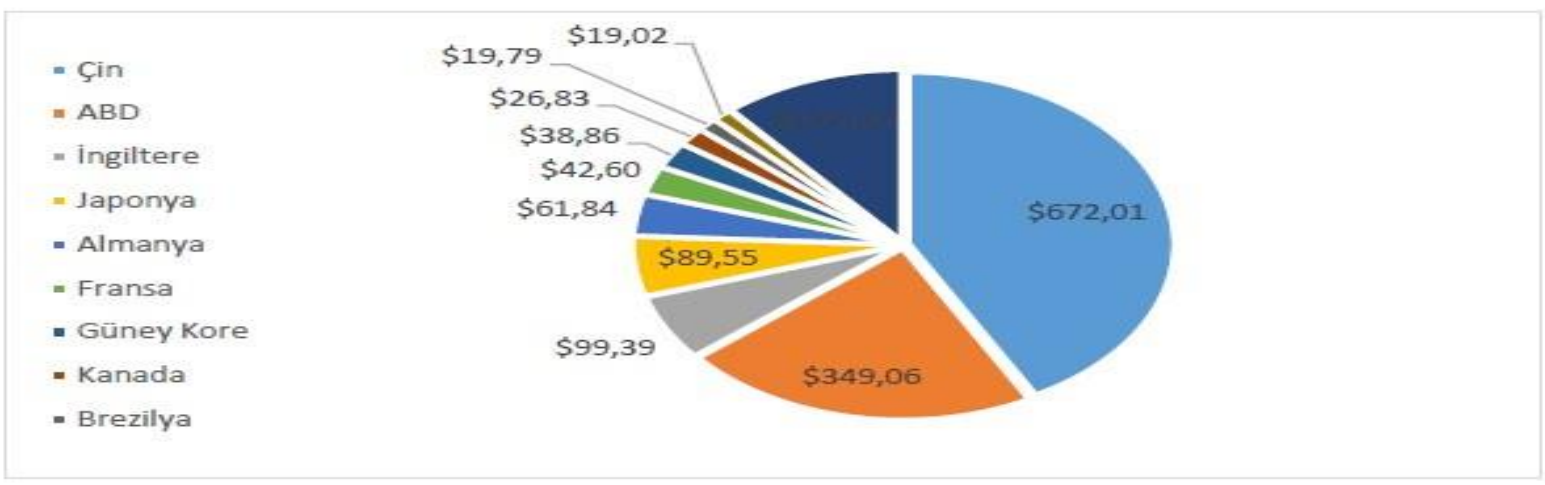

Grafik 3. Ülkelere Göre E-Ticaret, (Milyar \$), 2015

Kaynak: http://ebizstudy.org/_common/do.php?a=full\&b=12\&bidx=714\&aidx=9586

2016 verilerine göre de Çin'in hızlı büyüme oranlarını devam ettirerek global B2C e-ticaret hacminden en yüksek payı aldığı ifade edilmektedir. Bir önceki tabloda yer alan 2015 verilerini doğrular şekilde, 2016 yılında da Çin'in ardından ABD, İngiltere, Japonya, Fransa, Almanya, Güney Kore, Kanada, Hindistan ve Rusya’nın geldiği görülmektedir.

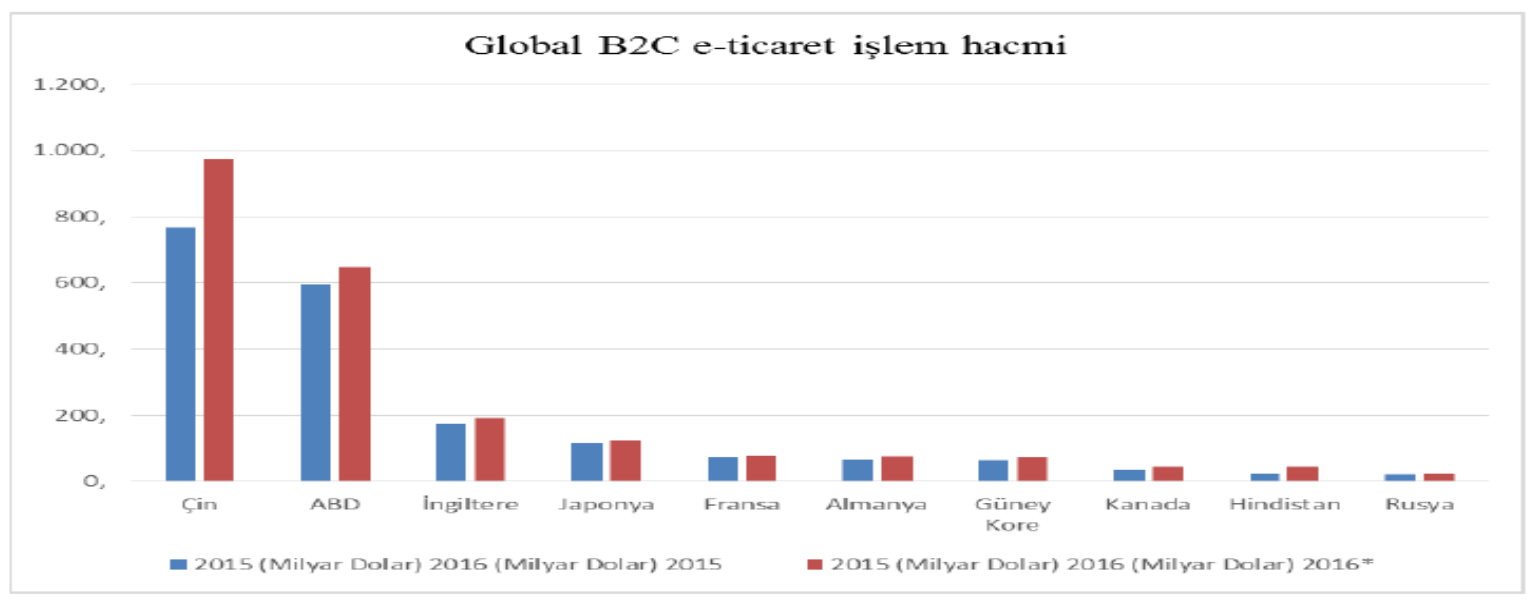

Grafik 4. Global B2C E-Ticaret İşlem Hacmi

Kaynak: https://www.statista.com/statistics/274493/worldwide-largest-e-commerce-markets-forecast/

Tıpkı geçmiş yıllarda olduğu gibi, 2017 yılında online perakende e-ticaret sektörünün büyümesine ilişkin öngörülerde Asya ülkelerinin gelecek 4 yıl içerisinde güçleneceği vurgulanmaktadır. Tahmin edilen rakamlar doğrultusunda, e-ticaret pazarının 2020'ye kadar Malezya'da \%23,7, Hindistan'da \%23, Endonezya'da \%20,7, Filipinler'de \%18,3 ve Çin'de ise \%17,4 oranında büyüyeceği ifade edilmektedir (www. Statisca.com). ABD'yi geçerek e-ticaret toplam hacminde ilk sıraya yerleşen Çin, e-ticaret'in gelişimi noktasında dünyada yer alan en önemli örneklerden birini teşkil etmektedir. Çin perakende sektöründe e-ticaretin payının 2015'te \%15,9 olduğu tahmin edilmekle birlikte bu oranın 2020 sonunda \%20'yi aşması beklenmektedir. Küresel e-ticaret ortamında Çin, $A B D$ ve Avrupa ülkelerinin mevcut yüksek pazar payları ve rekabet güçlerine karşın, gelişsmekte olan ülkelerde e-ticaret hacminin artışı büyük bir ivmeyle devam etmektedir. Hızla dijitalleşen 
dünyada rekabet gücünü korumak, pazardaki imkanlardan faydalanmak isteyen birçok ülke e- ticareti stratejik bir alan olarak değerlendirip, geliştirilmesine yönelik kapsamlı çalışmalarla büyük bir kararlılık sergilemektedir. Gelişmekte olan ülkelerde ekonomik kaynakların çeşitlenmesi, orta sınıfı oluşturan tüketicilerin artışı ve harcama eğilimlerinin artması eticaretin gelişimini köklü bir biçimde desteklemektedir. Ayrıca son yıllarda gelişmekte olan ülkelerin telekomünikasyon altyapılarını geliştirmeye yönelik ulusal politikalara ağılık vermesi, artan eğitim ve refah oranlarına bağlı olarak internet kullanımının ve internete erişebilirliğin artması da söz konusu ülkelerde e-ticaret'in gelişimi noktasında olumlu etkilerde bulunarak küresel e-ticaret'in bölgeler arasındaki uçurumları kapatmasına olanak sağlamaktadır. Hem gelişmiş hem de gelişmekte olan ülkelerde e-ticaretin artan hacmi ve kullanımı göz önünde bulundurulduğunda ise 2018'de 2.9 trilyon dolara ulaşması beklenen e-ticaret hacminin, 2020'de 4 trilyon doları aşması beklenmektedir. E-ticaret hacminin artması göz önünde bulundurulduğunda, işgücü piyasasında da hem doğrudan hem dolaylı istihdam artışı yaşanacak ve yeni iş ilişkilerinin gündeme gelmesi söz konusu olacaktır (Terzi, 2016a)

Türkiye, 12 Nisan 1994 tarihinde Orta Doğu Teknik Üniversitesi üzerinden sağlanan bağlantı ile ilk kez internetle tanışmıştır (Türen vd, 2011). Illk olarak üniversiteler, araştırma kurumları ve pilot bölgelerde erişilebilen internet kısa bir süre sonra ülke geneline ulaşmış, ВіT ve telekomünikasyon sektöründeki gelişmelere paralel olarak yüksek kullanım oranlarına ulaşmıştır. Elektronik Ticaret İşletmecileri Derneği'nin verilerine göre 2015 yılı rakamları doğrultusunda Türkiye e-ticaret perakende sektöründe \%2 paya sahiptir. Mevcut oran Türkiye'nin gelişmiş ve gelişmekte olan birçok ülkeden geride olduğunu gösteriyor. Örneğin Türkiye'de \%2 olarak ifade edilen bu oran aynı rapor kapsamında; Çin'de \%9.7, ABD'de \%9.2, Almanya'da yüzde \%9.2, Japonya'da \%7.2, Polonya'da \%6.8, Fransa'da \%6.8, Brezilya'da \%4.1, Rusya'da \%3.8, İspanya'da \%3.3 ve İtalya'da \%2.6 olarak ifade ediliyor. Fakat son yıllarda gerek telekomünikasyon altyapısına yapılan yatırımlar, gerek KOBI'lerin teşviki için gerçekleştirilen projeler ve en önemlisi AB ile uyum kapsamında oluşturulmaya başlanan yasal mevzuat Türkiye'nin gelecek yıllarda küresel e-ticaretten alacağı payın arttıracak önemli dönüşümleri beraberinde getirmektedir. Örneğin; Türkiye'nin e-ticaret potansiyelinin altını çizen McKinsey tarafından yayımlanan eticaret raporu Türkiye'nin 2023 yılında Dünya'nın en büyük 10 ekonomisinden biri olma hedefi, Avrupa genelinden 16 yaş genç olan nüfus avantajı ile birleşince Türkiye'yi e-ticaret sektöründe küresel alanda iddialı oyunculardan biri olarak öne çıkarmakta ve alanında dünya'da iddialı oyunculardan biri yapmaktadır ((www.mobilsiad.org) .

TÜiK verilerine göre; genişbant internet erişimine sahip hanelerin nüfusa oranı, 2016 yılı itibariyle \%73,1'dir (Grafik 5). Bu oranla birlikte, mobil ve genişbant penetrasyon oranlarında da önemli artışlar gözlenmektedir.
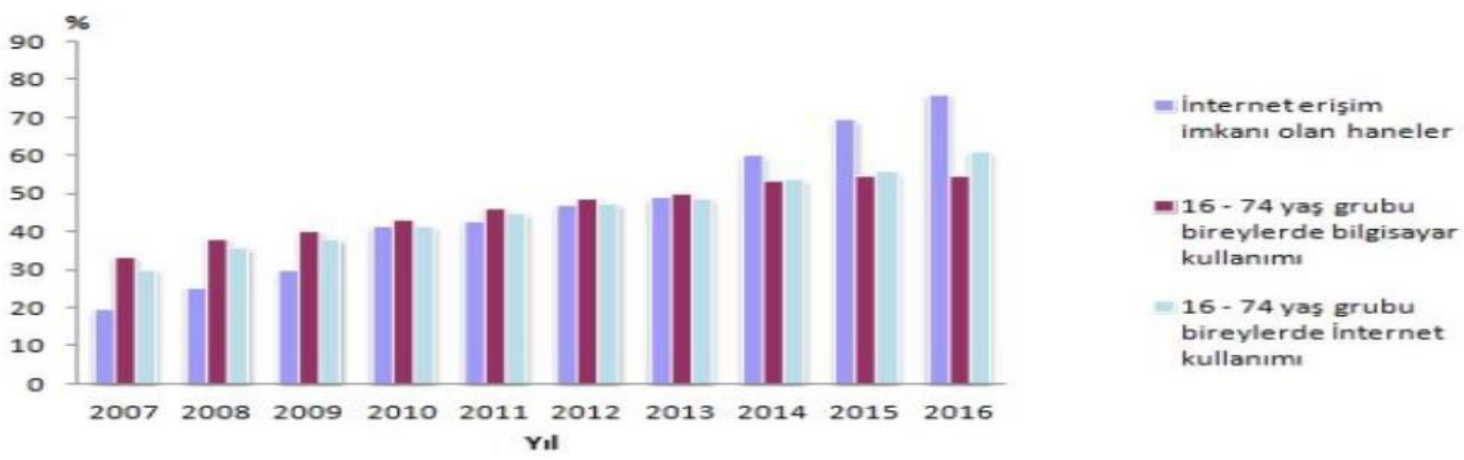

Grafik 5. Türkiye'de Internet Erişimi ve Kullanımı, 2016

Kaynak: http://www.tuik.gov.tr/PreHaberBultenleri.do?id=21779

2017 yılı verileri doğrultusunda, Türkiye mevcut internet kullanıcı sayısıyla dünya genelinde en fazla internet kullanıcısının olduğu ülkeler arasında gösterilmektedir (Grafik 6). 


\section{Grafik 6. Seçili Ülkelerde İnternet Kullanıcı Sayısı (2017)}

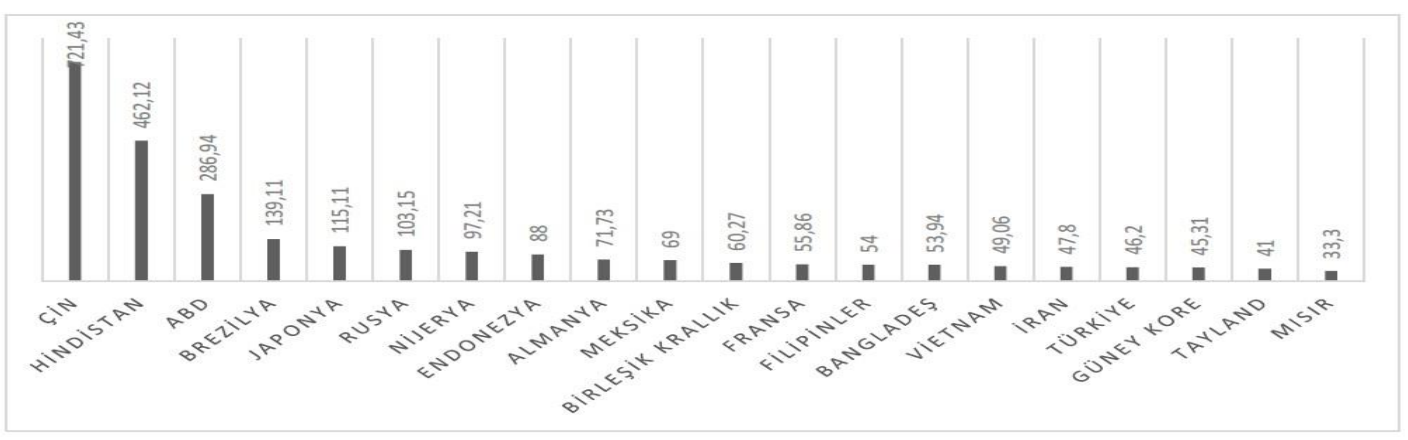

Kaynak: https://www.statista.com/statistics/262966/number-of-internet-users-in-selected-countries

İnternet kullanımının yaygınlaşmasının yanı sıra, Biт sektörünün ülke içerisindeki toplam cirosu yükselmekte, Biт 'den yararlanan işletmelerin sayısı her geçen gün artmakta ve yurtiçi-yurtdışı çevrimiçi alışverişin önündeki engeller kaldırılmakta, bu gelişimin bir sonucu olarak e-ticaretin boyut ve hacmi tüm dünyada olduğu gibi Türkiye'de de artış göstermektedir. Bu artışı ifade eden TÜBiSAD'in Deloitte ile yayınladığı ortak rapora göre; 2014 yılı sonunda Türkiye'nin e-ticaret hacmi 18,9 milyar TL'dir. 2015 verileri ise; e-ticaret hacminin 25 milyar TL'ye ulaştığını göstermektedir (www2.deleoitte.com). E-ticaret hacmindeki hızlı büyüme oranlarına karşın, Türkiye perakende pazarında e-ticaretin payı gelişmiş ülkelere kıyasla sınırlı kalmaktadır. Digital Positive tarafından yapılan araştırmaya göre Türkiye'nin en büyük 100 perakende firmasının 35'inin eticaret sitesi bulunmamaktadır (www.webrazzi.com).

Türkiye'de online alışverişi tercih eden internet kullanıcılarının oranı \%34,1 olarak belirtilmektedir. Tıpkı e-ticaretin pazar içerisindeki oranı gibi, tüketicilerin e-ticareti tercih etme oranı da gelişmiş ülkelerdeki yoğunluğun altındadır. Tüketiciler açısından bakıldığında; güvenliğe dair soru işaretleri hala e-ticaret'in gelişmesini engelleyen en önemli faktör olarak dikkat çekmektedir. Güvenlik sorunlarına ek olarak, ürün ve hizmet kalitesi, lojistik süreçlere dair yaşanılan sorunlar internet kullanıcılarını e-ticaret sitelerine karşı mesafeli bir duruşa yöneltebilmektedir. Elektronik ticaret'in gelişimi ile birlikte, sadece sektörel rekabet değil sektörler arası rekabet de hız kazanmıştı (Çak, 2002). Gelişmekte olan diğer ülkelerde olduğu gibi Türkiye'de de orta sınıfın yükselmesi, buna paralel bir şekilde harcama eğiliminin ve lüks tüketimin artması belirli sektörlerin e-satış oranlarını artırımaktadır. 2015 yılı rakamlarına göre, online perakende pazarı, tatil, seyahat ve yasal bahis harcamaları e-ticaret pazarında en yüksek payların sahibidir.

Perakende sektöründe en yüksek ciro oranları ise süpermarket kategorisine aittir. Doğrudan tüketici cevaplarına dayanan TÜiK verilerine göre e-ticarette en çok tercih edilen sektör ve kategoriler; internet üzerinden alışveriş yapan bireylerin 2015 yılı Nisan ile 2016 yılı Mart aylarını kapsayan on iki aylık dönemleri temel alındığında \%60 oranında giyim ve spor malzemesi, \%29,7'si seyahat bileti, araç kiralama vb, \%25,8'i ev eşyası (Mobilya, oyuncak, beyaz eşya vb), \%21'i elektronik araçlar (Cep telefonu, kamera, radyo, TV, DVD oynatıcı vb.), \%19,8'i gıda maddeleri ile günlük gereksinimler (çiçek, kozmetik, tütün ve içeceklerin de dahil) şeklindedir (www.tuik.gov.tr).

Dünya geneli rakamlarıyla karşılaştıııldığında Türkiye'de yapılan online seyahat harcamaları da e-ticaret harcamaları arasında önemli bir yer tutmaktadır. İspanya ve Birleşik Krallığın ardından Türkiye, online seyahat harcamalarının en çok görüldüğü 3. ülkedir. 


\section{Grafik 7: Online Seyahat Harcamaları}

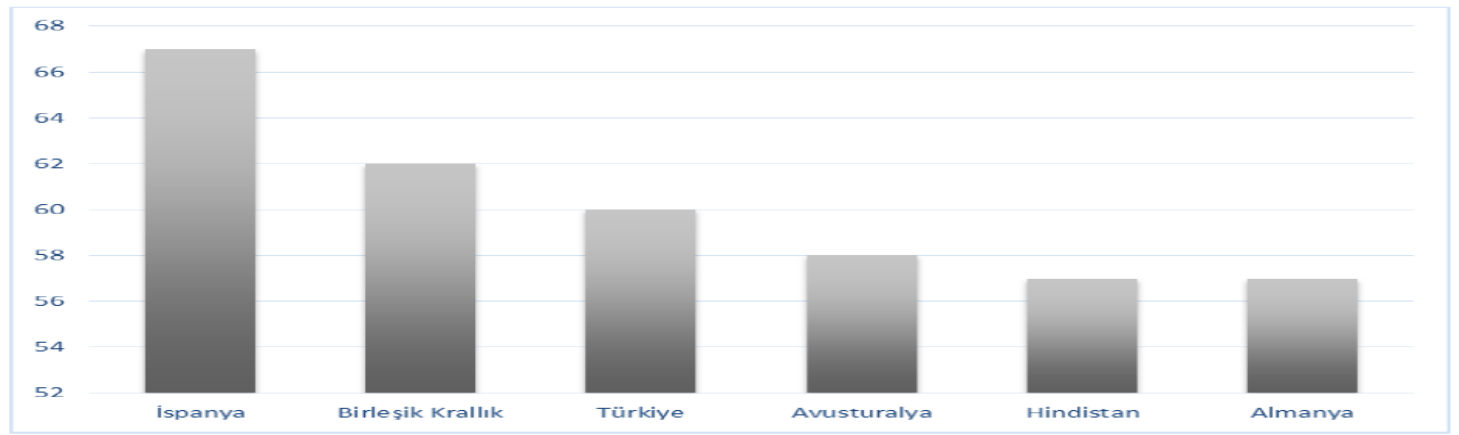

Kaynak: https://www.statista.com/statistics/505197/top-countries-online-travel-sales/

Aşağıdaki tablo Türkiye'de e-ticaretin önündeki fırsatları ve aşılması gerekli tehditleri ekonomik, teknik, sosyal ve yasal açıdan özetlemektedir (Tablo 1).

Tablo 1: Türkiye'nin E-Ticarette Fırsat ve Tehditleri

\begin{tabular}{|c|c|c|}
\hline & Firsatlar & Tehditler \\
\hline $\begin{array}{l}\text { Ekonomik } \\
\text { Boyut }\end{array}$ & $\begin{array}{l}\text { Alıcı-satıcı sayısındaki artış Kart kullanımı } \\
\text { yaygınlaşıyor Yabancı yatırımcı fırsatı } \\
\text { artıyor Yeni iş piyasaları açılıyor Lojistik } \\
\text { altyapı güçleniyor KOBi'ler için yeni } \\
\text { pazarlar yaratıyor }\end{array}$ & $\begin{array}{l}\text { Melek yatırımcı gibi finansal destekler artsa da } \\
\text { henüz istenilen düzeye ulaşmamıştır } \\
\text { Online siparişler toplam siparişlerin küçük bir } \\
\text { bölümünü oluşturmaktadır Online siparişler daha } \\
\text { çok iç piyasa temellidir, e-ihracat düşük düzeydedir } \\
\text { Alternatif ödeme sistemleri azdır Online firma } \\
\text { sayısı az sayıdadır KOBi'lerde e- ticaret yaygın bir } \\
\text { şekilde kullanıl-mamaktadır }\end{array}$ \\
\hline Teknik Boyut & $\begin{array}{l}\text { Telekomünikasyon alt yapısı gelişiyor Abone } \\
\text { sayısı artıyor } \\
\text { Mobil ticaret artıyor } \\
\text { Yeni ödeme sistemleri gelişiyor ve } \\
\text { yaygınlaşıyor }\end{array}$ & $\begin{array}{l}\text { B2B ve B2C e-ticaret düşük düzeydedir Dijital } \\
\text { okuryazarlık düşük boyutlardadır } \\
\begin{array}{ll}\text { Bağlantı } & \text { konusunda bölge-ler } \\
& \text { arasında farklılaşma yaşanmaktadır }\end{array}\end{array}$ \\
\hline Sosyal & $\begin{array}{l}\text { Avrupa ve Asya arasında güçlü sosyal } \\
\text { bağlantılar kuruluyor ve yaygınlaşıyor Sosyal } \\
\text { medya kullanımı artıyor } \\
\text { Sosyal medya kadın girişimci sayısını artırıyor }\end{array}$ & $\begin{array}{l}\text { Internetin dışında olan ya da hiç bilmeyen bireyler } \\
\text { bulunmaktadır } \\
\text { Gençlerde sosyal amaçlı internet kullanımı yaygın, } \\
\text { bu durum gelecek için bir tehdit oluşturabilir }\end{array}$ \\
\hline Yasal & $\begin{array}{l}\text { E-ticarete ilişkin yasal temel } \\
\text { oluşturuluyor } \\
\text { E-ticaret hukuku Avrupa hukuku ile } \\
\text { uyumlaştırılıyor }\end{array}$ & $\begin{array}{l}\text { Ödeme sistemlerine ilişkin güvenlik problemi } \\
\text { devam ediyor } \\
\text { Diğer ülkeler ile e-ticaret hukukun birbirine } \\
\text { yakınlaştırılmasına ihtiyaç var } \\
\text { AB ile uyum tam olarak sağlanmış değil }\end{array}$ \\
\hline
\end{tabular}

Kaynak: Terzi, 2016b.

Genç ve dinamik nüfus avantajı, lojistik açısından coğrafi olarak ayrıcalıkı konumu, Asya-Pasifik gibi önemli pazarlara yakınlığı, Avrupa Birliği'ne aday ülke olarak sahip olduğu birtakım ayrıcalık ve fonlar Türkiye'nin küresel e-ticaret 
pazarındaki hacminin yavaş adımlarla da olsa artmasında önemli roller üstlenmektedir. Söz konusu avantajların kullanılması ile birlikte, Türkiye ekonomisi küresel e-ticaretin kalkındırıcı ve geliştirici etkisinden faydalanmaya devam edecektir.

Türkiye'de e-ticaret hem mevcut hem de yeni girişimciler için önemli fırsatlar yaratmaktadır. Sadece iç piyasa potansiyelini değil aynı zamanda da dış piyasalarda da firmaların potansiyelini artırmaktadır. Üstelik istihdam piyasasına da önemli katkılarda bulunmaktadır. Gerek genç istihdam gerekse kadın girşimci sayısının atmasında önemli rol oynamaktadır. Kullanıcı sayısındaki artış telekomünikasyon altyapısındaki gelişmeler Türkiye'de e-ticareti önemli boyutlara taşıyacaktır. Bununla birlikte dijital okuryazarlığın yaygınlaştırılmasına ve hukuksal altyapının geliştirilmesine ihtiyaç duymaktadır. Özellikle ödeme sistemlerine ilişkin güvenlik sorunu hala devam etmektedir. Ekonomik, teknik, sosyal ve yasal açıdan pek çok fırsatı elinde bulunduran Türkiye'deki e-ticaret pazarı, mevcut sorunların aşımasıyla küresel eticaret piyasasında önemli bir yere sahip olacaktır (Terzi, 2017).

\subsection{E-TICARETTE KULLANILAN PAZARLAMA STRATEJILERI}

1984 yılında Amerikan Pazarlama Derneği tarafından yapılan tanıma göre pazarlama; ürün, hizmet ve fikirlerin geliştirilmesi, fiyatlandırılması, tutundurulması ve dağıtımına ilişkin planlama ve uygulama süreci olarak ifade edilmektedir. İşletmelerin sahip oldukları pazarlama kaynaklarının çeşitliliği ve boyutları rekabet avantajı elde etmelerinde belirleyici olmaktadır. İnternet üzerinden gerçekleştirilen sanal pazarlama faaliyetleri; işletmelerin zorlu rekabet ortamında farklılaşarak, hedef kitlelerine daha kolay ulaşabilmelerini, müşteri ilişkilerini etkileşimli bir biçimde yönetebilmelerini, promosyon ve dağıtım süreçlerinde para ve zaman tasarrufu sağlamalarını mümkün hale getirir. Kimi işletmeler sanal ortamları yalnızca reklam ve tanıtım için kullanılırken, kimi işletmeler için sanal ortam her türü pazarlama eylemlerinin yerine getirilmesi adına eşi bulunmaz bir fırsat niteliğindedir (Yurdakul ve Kiracı, 2008). Pazarlama stratejileri e-ticarettin gelişimi için önemli avantajlar sunmaktadır. Elektronik ticarette en yaygın olarak kullanılan pazarlama stratejileri; içerik pazarlaması, e-posta pazarlaması, arama motoru pazarlaması(SEO), sosyal medya pazarlaması, çoklu kanal pazarlaması ve viral pazarlamadır.

\section{içerik Pazarlaması}

Içcerik pazarlama; belirli bir değeri olan, özgün, faydalı, ilgi çekici ve süreklilik arz eden içeriklerin yaratımı ve dağııımı ile hedef kitlenin dikkatini çekerek yeni müşteri kazanmayı hedefleyen pazarlama stratejisidir. İçerik pazarlamadaki en önemli amaç; tüketicilerdeki satın alma alışkanlıklarını değiştirmek ve arka planda pazarlanan ürüne karşı satın alma isteği oluşturmaktır. Bu tanımdan hareketle içerik pazarlaması temel olarak; herhangi bir satış işlemi olmaksızın müşteriler ve potansiyel müşterilerle iletişim kurma süreci olarak da tanımlanabilmektedir (Altınışık ve Bilge, 2014). İçerik pazarlamasını en çok tercih edilen e-ticaret stratejilerinden yapan nedenlerin başında ise; günümüzde işletmelerin çeşitli mecralarda yalnızca ürünlerini tanıtmasının yetersiz kalmasıdır. Tüketiciler artık doğrudan pazarlama yapan içeriklere ilgilerini kaybetmiş durumdadırlar, hatta reklamlara karşı bir direnç mekanizması geliştirmişlerdir (Todor, 2016).

Türkiye İstatistik Kurumu tarafından gerçekleştirilen “Hanehalkı Bilişim Teknolojileri Kullanım Araştırması”nın sonuçlarına göre; Türkiye'de yaklaşık olarak 4 internet kullanıcısından 3'ü interneti paylaşım sitelerinden video izleme, blog, gazete, dergi okuma ve bilgi edinme amaçlı kullanıyor. Bu verileri e-ticaret perspektifinden değerlendirecek olursak, direkt olarak reklam algısı yaratan içeriklerden sıkılan tüketicilere ulaşmanın en kolay ve etkili yolun, sosyal medya platformları başta olmak üzere dijital mecralarda özgün, ilgi çekici ve paylaşılabilir içerikler üretmekten geçtiği görülmektedir.

\section{E-posta Pazarlaması}

E-posta ile pazarlama, e-ticarette uzun zamandır kullanılan ve halen internet üzerinden gerçekleştirilen pazarlama faaliyetlerinde en sık kullanılan stratejilerden biridir. E-posta pazarlamasında; ürün, hizmet veya markaya ilişkin bilgilendirme, haber veya promosyon doğrudan kitlelere ulaştırılarak; iletişim, tanıtım ve satış faaliyetleri gerçekleştirilmiş olur (Ünal, 2012). Günümüzde bir e-mail hesabına sahip olmak, iş yaşamından eğitime birçok alanda diğer bireylerle iletişim kurabilmek, bilgi ve belge paylaşımında bulunmak adına adeta bir zorunluluk haline gelmiştir. Türkiye'de internet kullanıcılarının \%44'ünün düzenli olarak e- mail portallarını ziyaret ettiği tahmin edilmekte, Norveç ve Polonya gibi Avrupa ülkelerinde ise internet kullanıcılarının e-mail portallarıyla penetrasyon oranı \%70'i geçmektedir. Yaygın kullanım oranının yanı sıra çok düşük maliyetlerle potansiyel müşteri ve müşterilere ulaşabilmenin mümkün olması, altyapı, tasarım ve strateji açısından kolay uygulanabilirliği e- mail pazarlamasının diğer avantajlarıdır. Gönderilen e-postanın içeriği, doğru zamanlamanın yapılması ve doğru promosyonların sunulmasının yanı sıra, bu yöntemi tercih eden işletmelerin dikkat etmesi gereken en önemli noktanın "izin" olduğu belirtilmektedir. Bu şekilde bir izin ve gönüllülük temelinde gerçekleşmeyen e-posta pazarlamaları, markanın imajına zarar verirken, müşterinin kaybedilmesiyle sonuçlanabilmektedir. İzinli pazarlama müşterinin güveni sağlamanın önemli yollarından biridir. 


\section{Arama Motoru Pazarlaması}

İnternet üzerinde var olan bilgileri sorgulamayı ve saniyeler içerisinde istenilen bilgiye ulaşmayı sağlayan arama motorları; web robotu, arama indeksi ve kullanıcı arabiriminden oluşmaktadır (Yurdakul, 2016). Arama motorlarının öne çıkan işlevleri şu şekilde ifade edilmektedir (France vd,2002);

$\checkmark$ Kullanıcıların internet üzerinde var olan bilgi ve belgelere ulaşabilmeleri için mevcut web sayfalarını belirli düzende bir araya toplamak,

$\checkmark$ Biraraya getirilen bu içerikleri kullanıcıya belirli bir sıralama dahilinde sunmak,

$\checkmark$ Kullanıcıları, aradıkları bilgiler doğrultusunda en yakın sonuca ulaştırabilmek için algoritmaların araştırılması.

Bu üç temel fonksiyonuyla internet kullanıcıları için vazgeçilemez bir araç olan arama motorları, zaman içerisinde mevcut fonksiyonuna yeni bir boyut ekleyerek firmaları hedefledikleri müşteri kitleleriyle buluşturan bir yapı haline gelmiştir (Sevindik, 2009). Firmaların bu alandaki pazarlama potansiyelini en etkili şekilde değerlendirmek, rakipleri arasından sıyrılıp, görünürlülüklerini arttırmak istemeleri ise arama motoru optimizasyonu, yaygın kullanılan şekliyle SEO (Search Engine Optimization) kavramını beraberinde getirmiştir. Site ve sayfaların arama motorları tarafından daha kolay bulunup endekslenmesi ve kullanıcılara en üst sıralarda gösterilmesi için yapılması gereken işlemleri ifade eden SEO, internet üzerinden potansiyel alıcılara ulaşmanın en hızlı, ekonomik ve etkili yöntemi olarak görülmektedir. Dünyanın en çok kullanılan arama motoru olan Google'ın, dünya genelindeki bütün reklam gelirlerinin üçte birine sahip olması, SEO'nun eticaret pazarlamasında en çok tercih edilen yöntemlerin başında geldiğini doğrulamaktadır. SEO pazarlamasının e-ticarete getirdiği en büyük yenilik, düşük bütçelerle doğrudan hedeflenen müşteri kitlesine ulaşılabilmesi, bunun yanı sıra hiçbir reklam ücreti ödemeden de sadece web sitesinin yapısının optimize edilmesiyle marka görünürlülügünün ve dolayısıyla satışların arttırılması olmuştur (ışık, 2013). Arama motorlarının sağladığı çeşitli araç ve yöntemlerle ulaşılan kitleyi ölçümlemek, analiz etmek, geri bildirimler doğrultusunda mevcut stratejiyi değiştirebilme esnekliği ise SEO'yu sadece bir reklam yöntemi olmaktan çıkararak daha kapsamlı bir pazarlama yöntemi olarak değerlendirilmesini sağlamıştır.

\section{Sosyal Medya Pazarlaması}

Yeni iletişim ortamlarının gelişmesi, bilgi ve iletiş im teknolojilerine ilginin artmasıyla; kişiler ve kitlelerarası iletişim televizyon, gazete, dergi, telefon ve radyo gibi geleneksel iletişim araçlarından ziyade ağlar üzerinden yürütülmeye başlanmıştır. WEB 2.0 teknolojisiyle internetin tek yönlü iletişime odaklı yapısı değişmiş; bireylerin daha aktif olduğu, içeriklere müdahale edip kendi içeriklerini yaratabildikleri yeni bir ekosistem meydana gelmiştir(Kara, 2016). Bu ekosistemin önemli bir parçasını oluşturan sosyal medya ise iletişim kavramına yeni bir boyut eklemiştir. Bireylerin sosyalleştiği, kendi içeriklerini oluşturup fikir ve görüşlerini paylaştıkları sanal platformlar, şirketler ve gerçekleştirdikleri pazarlama faaliyetleri açısından önemli bir alanı temsil etmektedir (Akar, 2011). Bu alanı oluşturan ve her geçen gün sayıları artan başlıca sosyal medya platformları arasında Facebook, Twitter, Instagram ve Pinterest yer almaktadır.

\section{Çoklu Kanal Pazarlaması}

Tüketicilerin günlük hayatlarının bir parçası olarak kullandıkları araç ve platformların sayısı artmakta, bunun sonucu olarak internet üzerinden pazarlanan bir ürün veya hizmete ulaşma biçimleri de çeşitlilik göstermektedir. Yapılan araştırmalar tüketicilerin yarısından fazlasının çevrimiçi veya fiziksel mağazalardan bir ürün almadan önce internette fiyat araştırması yaptığını, satın alma kararını vermeden önce farklı kanalları kullanarak derinlemesine bir fikir sahibi olmak istediklerini göstermektedir (Fulgoni, 2014). Müşteri davranışlarında gözlemlenen bu aktiflik; e-ticaret pazarlamasında kullanılan temel stratejilerin bir arada kullanılması gerekliliğini doğurmuştur. Pazarlama sürecinde söz konusu stratejilerin bir arada kullanılmasını ifade eden "çevrimiçi çoklu kanal pazarlaması" firmaların en çok yatırım yaptığı stratejilerden biri haline gelmiştir. Çoklu kanal pazarlamasının müşterilere yönelik hedefi iki aşamadan oluşmaktadır. Bunların ilki müşterilere marka ve ürüne ulaşabilmeleri için daha çok seçenek sunarak karar alma aşamasından satın alma aşamasına kadar müşterinin alışveriş deneyimini kolaylaştırmak, diğeri ise müşteri davranışlarını yönlendirmek ve ölçümlemek olarak tanımlanabilir (Copra, 2016).

Çoklu kanal pazarlamasında; sosyal medya pazarlaması, SEO, e-posta pazarlaması ile birlikte televizyon, radyo, gazete gibi geleneksel medya platformlarından da faydalanılmaktadır. Bu stratejinin uygulanması doğrultusunda tüketicinin markaya ulaşma potansiyeli önemli ölçüde gelişmektedir. Örneğin; e-posta reklamıyla ürün veya hizmete ulaşan tüketici; ardından arama motorlarını kullanıp firmanın sitesine ulaşabilmekte, daha sonra sosyal medya platformlarında markayı ve ürün/hizmeti inceleyerek satın alma kararı verebilmektedir. Genel olarak, e-ticarette uygulanan sanal pazarlama stratejilerinin firmalar açısından yarattığı en büyük zorluk, farklı kanallara yönelik farklı stratejiler geliştirilmesi gerekliliği düşüncesidir. Çoklu kanal pazarlaması ise bu yaklaşımdan tamamen farklı bir şekilde, aynı stratejinin farklı kanallarda 
uyumlu bir şekilde kullanılmasını ifade eder. Çok kanallı pazarlama stratejisini uygulayabilmek için firmaların öncelikle hedef kitlelerini ve hedef kitlelerine ulaşabilecekleri platform ve araçları tanımalıdırlar. Tüketicinin nerede olduğunu bilen firmalar, birden çok pazarlama stratejisi yerine, mevcut pazarlama stratejilerini kapsamlı ve tüm kanallara uyumlu bir hale getirip önemli avantajlar kazanmaktadırlar. İstenilen verimin alınması ise bu noktada uygulanacak stratejinin kapsamına ve diğer pazarlama yöntemlerine tamamen entegre edilmesine bağlıdır. Bu stratejiyi kullanarak, pazarlama açısından önemli getiriler elde eden firmaların sayısı her geçen gün artmaktadır. Çoklu kanal pazarlaması özellikle hem fiziksel hem çevrimiçi mağazası olan firmalar için en cazip pazarlama seçeneği olarak öne çıkmaktadır. Nitekim; hem fiziksel hem de çevrimiçi mağazaları aracılığı ile teknolojik ürünler satan TeknoSA, 2014 yılında çoklu kanal yapılanması için 60 milyon TL yatırım yapmıştır (www.marketingturkiye.com).

\section{Viral Pazarlama}

Pazarlama stratejilerinin hedef kitlesini oluşturan tüketiciler aynı zamanda diğer tüketicilerle birlikte sözel ve biçimsel olmayan bir iletişim ağını oluşturur ve bu ağ içerisinde birbirlerinin satın alma kararlarına etkide bulunurlar (Argan ve Tokay, 2016). Word of mouth yani "ağızdan ağıza" olarak tanımlanan bu iletişim çeşidi bireylerin farkındalığını, marka algısını, tutum ve davranışlarını şekillendirme işlevine sahiptir. Bireylerin sadece yakın çevreleriyle değil, hem ulusal hem de global sınırlar çerçevesinde binlerce hatta milyonlarca insanla iletişime geçebilmesine imkan sağlayan sosyal medya platformları ve diğer internet teknolojileri bu iletişim yöntemini firmaların en sık yararlandığı pazarlama stratejilerinden biri haline getirmiştir. Viral pazarlama olarak adlandırılan bu strateji, internet kullanıcılarının bir pazarlama mesajını diğer kullanıılara gönüllü bir şekilde aktarmalarını teşvik eden ve ürün/hizmet reklamının bu yolla gerçekleştirilmesini amaçlamaktadır. Etkisi virüs yayılımına benzetilen viral pazarlama stratejisinde hedef, mesajın binlerce kişiden yüzbinlerce hatta milyonlarca kişiye hızlı ve maliyetsiz bir şekilde yayılmasıdır (Argan ve Tokay, 2016). Hem tüketicilerin hem de satıcıların viral pazarlamaya yoğun bir ilgi göstermesinin birçok nedeni vardır. Tüketiciler açısından bakıldığında, diğer alıcıların ürün/hizmet ve marka hakkındaki organik deneyimleri, geri bildirimleri karar alma sürecini güvenilir bir şekilde sonlandırmaya imkan vermektedir. Satıcı perspektifinden yaklaşıldığında ise, viral pazarlama düşük maliyetlerle sunulan ürün ve hizmeti satın alma potansiyeline sahip tüketicilere hızlı ve etkili bir şekilde pazarlama yapma fırsatı sunar. Bu nedenle viral pazarlama e-ticarete yoğunlaşan firmalar için ayrı bir önem arz etmektedir. Maliyet ve hız avantajlarının yanı sıra geri bildirim alma noktasında da viral pazarlamanın sağladığı avantaj, büyüklüğü ve sektörü farketmeksizin bütün işletmeler için cezbedici bir faktör haline gelmiş böylece son yıllarda viral pazarlama uygulamaları hızla artarak görselliğin yoğun biçimde var olduğu popüler bir strateji haline gelmiştir.

\section{VERI VE YÖNTEM}

Sanal pazarlama stratejilerinin ekonomi üzerindeki etkileri üreticiler ve tüketiciler açısından değerlendirilmektedir. Eticarette yer alan iki önemli firma Yemeksepeti ve Markafoni üreticiler açısından değerlendirme için seçilmişlerdir. Yemeksepeti ve Markafoni'nin sanal pazarlama stratejilerinin ekonomiye etkisinin değerlendirilmesinde kendi sayfalarında yer alan veriler ve diğer kaynaklardaki yer alan verilerden yararlanılmıştır. Tüketiciler açısından değerlendirmede anket formundan yararlanılmıştır. 524 kişinin katıldığı bir anket çalışması gerçekleştirilmiştir. Anket 13 sorudan oluşmaktadır. İlk dört soru katılımcıların cinsiyet, yaş, eğitim ve gelir bilgilerini ölçmeye yöneliktir. Formda yer alan diğer sorular ise katılımcıların çevrimiçi alışveriş sıklıklarını, çevrimiçi alışverişte göz önünde bulundurdukları kriterleri, sanal pazarlama stratejilerine karşı tepkilerini ve en çok tercih ettikleri internet girişimlerini incelemeye yöneliktir.

\section{BULGULAR VE TARTIŞMA}

\section{1. Üretici Açısından Bulgular ve Tartışma}

\section{Yemeksepeti.com}

Türkiye'nin ilk internet girişimlerinden biri olan yemeksepeti.com aynı zamanda ilk ve en gelişmiş online yemek sipariş sitesidir.Yemeksepeti.com; Nevzat Aydın, Melih Ödemiş ve Cem Nufisi tarafından 2001 yılında yaklaşık 150.000 dolarlık bir sermaye ile kurulmuştur (www.kigem.com). "Yemek Sepeti Gıda ve Pazarlama Elektronik İletişim ve Tanıtım Limited Şirketi” adı altında çalışmaya başlayan yemeksepeti.com, İstanbul'da bulunan restoranları tek bir platform altında toplayarak kullanıcıların yemek siparişlerini çevrimiçi bir şekilde vermeleri hedefiyle 26 restoranla internet kullanıcılarına hizmet vermeye başlamıştır.2010 yılında Rusya'da, 2013 yılında Katar, Suudi Arabistan ve Lübnan'da hizmet vermeye başlayan yemeksepeti, son olarak 2014 yıında ifood.jo'nun çoğunluk hisselerini satın alarak Ürdün pazarına açılmıştır. Yemek Sepeti şu anda Türkiye'de 64 şehirde ve Kuzey Kıbrıs Türk Cumhuriyeti'nde 13.000'in üzerinde üye restoranla hizmet vermekte ve günlük olarak ortalama 150.000 sipariş almaktadır. Üye kullanıcı sayısının ise beş milyonun üzerinde olduğu belirtilmektedir (www.teknolojituru.com). 


\section{Yemeksepeti'nin Pazarlama stratejileri}

Yemeksepeti geliştirdiği farklı iş modeli ile Türkiye e-ticaret ekosisteminde rakibi olmayan bir girişim olarak öne çıkmaktadır. Yemeksepeti'nin başarısı pazarda rakipsiz oluşunun yanı sıra kuruluşundan bugüne başarıyla uyguladığı sanal pazarlama stratejileriyle de yakından alakalıdır. Hedef kitleyi tanıma aşamasından kanal seçimi ve stratejilerin uygulanmasına kadar geçen süre içerisinde müşteri odaklılık ve yenilik ilkelerini benimseyen firma özellikle içerik ve sosyal medya pazarlamasında farklılaşan ve örnek gösterilen projeler gerçekleştirmektedir. Elektronik ticaretin gelişimine paralel olarak yaygınlaşan ve önem kazanan içerik pazarlaması; hedef kitleye ulaşma, potansiyel müşterilerin ilgisini çekme, var olan müşterilerin ilgisini canlı tutma ve marka ile ilişki kurabilmelerini sağlama amacıyla e- ticaret girişimleri tarafından yoğun olarak kullanılmaktadır. Türkiye'nin en başarılı internet ve e-ticaret girişimlerinden biri olan Yemeksepeti ise içerik pazarlamasını başarılı bir şekilde gerçekleştirmektedir. Güncel olaylar, özel günler ve önemli tarihlerin içerik haline dönüştürüldüğü projelerin yanı sıra, tüketicilere özel hazırlanan içerikler Yemeksepeti tarafından uygulanan içerik pazarlama stratejilerinin temelini oluşturmaktadır.

Yemeksepeti'nin; mevcut ve potansiyel müşterileriyle iletişim kurmak için kullandığı kanalların biri de sosyal medya platformları gelmektedir. Bu platformlardaki iletişime, marka imajına önem veren firma, sosyal medya pazarlamasını da etkin bir biçimde gerçekleştirmektedir. Bu platformlara yönelik stratejilerin temelini ise takipçilerle etkileşim yaratabilecek içeriklerin paylaşılması, takipçilerin Facebook, Twitter ve Instagram üzerinden düzenlenen yarışma ve kampanyalara katılımlarının arttırılması oluşturmaktadır. Takipçilere yemek siparişlerindeki tercihleri sorularak etkileşimli stratejiler yaratılmaktadır. Tematik hashtaglerin yer aldığı sosyal medya kampanyaları sonucunda, yorum yazan veya seçili hashtagi kullanan kullanıcılar yemek çekleri veya indirimler kazanabilmektedir.

Kullanıcılara günün belirli zamanlarda anlık olarak sunulan joker indirimler yemeksepetinin pazarlama stratejisinde önemli bir yere sahiptir. Üye restoranlarla birlikte düzenlenen bu promosyonlar genellikle sipariş yoğunluğunun az olduğu saatlerde veriliyor. Joker indirimden yararlanmak için belirli bir oranda sipariş verme zorunluluğun olması kullanıcıların yapacakları harcamaların miktarını da arttırmaktadır.

\section{Yemeksepti.com'un Pazarlama Stratejilerinin Ekonomiye Etkisi}

Yemeksepeti, tüm bu pazarlama stratejilerini de kullanarak kazandığı beş milyonu aşan kullanıcı sayısı ve yüksek büyüme oranlarının yanı sıra aldığı yabancı yatııımlarla da e-ticaret ekosisteminde önemli bir yer teşkil etmektedir. Yemeksepeti ilk yatırımını 2012 yılında dünyanın en büyük özel sermaye fonlarından biri olan ABD merkezli General Atlantic'den aldı. 44 milyon dolar değerinde olan bu yatırım aynı zamanda şirketin Türkiye'deki ilk yatırım faaliyeti olma özelliği taşımaktadır. 2015 yılında ise 33 ülkede faaliyet gösteren global yemek sipariş platformu Delivery Hero, Yemeksepeti'nin hisselerinin tamamını 589 milyon dolar değerlendirme üzerinden satın almıştır. Bu satın alma aynı zamanda Türkiye'de gerçekleşen en büyük internet satışını göstermektedir.

E- ticaret girişimlerinin geliştirdikleri yeni iş modelleri sayesinde farklı istihdam alanları açtığı ve ülkelerin ekonomilerine önemli katkılar sağladığı kabul edilmektedir. Bu bağlamda Türkiye'nin en büyük e-ticaret girişimlerinden biri olan Yemeksepeti'nin istihdam üzerindeki olumlu etkileri önem arz etmektedir. 2016 yılı itibariyle firmanın 500'e yakın beyaz yakalı çalışan istihdam etmektedir. Yaş ortalaması 26 olan organizasyonun içerisinde; bilgi teknolojileri ve yazılım uzmanları, dijital pazarlama ve sosyal pazarlama alanında çalışan reklamcılar, ürün yönetimi ve iş geliştirme uzmanları, insan kaynakları ve restoran ilişkilerinden sorumlu çalışanların yanı sıra muhasebe, çağrı merkezi, idari işler müşteri hizmetleri ve operasyon departmanlarında görev alan genç bir çalışan kitlesi mevcuttur. Yemneksepeti.com istihdama katkı sağlamakla kalmamış, aynı zamanda yeni iş alanlarının açılmasını da sağlamıştır. Üstelik oldukça genç olan çalışan profilinin \% 80 'inin yükseköğrenim görmüş olması ve bu bireylerin BiT, dijital pazarlama gibi e-ticaretin gelişimi açısından kritik önem arz eden alanlarda istihdam edilmesi; e-ticaretin gelişmesi ve Türkiye'nin bu sektörlerden elde ettiği katma değerin artmasına önemli katkılar da bulunmuştur.

Yemeksepeti'nin kendi organizasyon yapısı dışında anlaşmalı işyerlerine ve genel olarak yeme-içme sektörüne yaptığı katkı da istihdam açısından olumlu sonuçlar doğurabilecek gelişmeleri beraberinde getirmiştir. Bu e-ticaret sektörünün dolaylı istihdama da katkı sağladğının önemli bir kanıtıdır. Nitekim 2016 yılı verilerine göre Yemeksepeti ile çalışan restoranların yıllık ortalama ciro artışının \%36 olduğu belirtilmektedir (www.teknolojituru.com). Pazarlama ve operasyon aşamalarında verilen destekler restoranların daha hızlı büyümelerine ve istihdam edilen personel sayısının artmasına imkan vererek hem yeme-içme sektörüne hem de istihdam yapısına olumlu etkilerde bulunmaktadır. Yemeksepeti'nin 13.000'in üzerinde üye işyeri ile çalıştığı göz önünde bulundurulduğunda istihdam üzerindeki bu etkinin dikkate değer olduğu sonucu ortaya çıkmaktadır. 


\section{Markafoni.com}

2008 yılında kurulan Markafoni Türkiye'nin internet üzerinden hizmet veren ilk özel alışveriş sitesidir. 7 milyonu aşkın kullanıcısı olduğu ifade edilen Markafoni, giyim, dekorasyon, kozmetik gibi bir çok kategoride yerel ve global markaları \%90'a varan indirimlerle sunan site üyelik sistemi ile çalışmaktadır. Elektronik posta aracılığıyla siteye kaydolan kullanıcılar, gelecek kampanyaların içeriği ve indirim oranlarına ilişkin haberdar edilmektedir."Impulse buy" olarak adlandırılan pazarlama stratejisiyle; zaman baskısı ve fiyat avantajlarının bir arada sunulmasıyla tüketicileri alışverişe teşvik etmeyi amaçlayan site; özel alışveriş kulüplerinin ülkemizde yaygınlaşmasında önemli rol oynamıştır. Markafoni, özel alışveriş sitelerinin Türkiye'deki ilk örneği olmasının yanı sıra, aldığı yerli ve yabancı yatırımlar, kullanıcı sayısı ve satış oranlarıyla da ülkemizin e-ticaret ekosistemi içerisinde stratejik bir öneme sahiptir.

\section{Markafoni'nin Pazarlama Stratejileri}

Markafoni'nin aynı iş modeliyle faaliyet gösteren rakiplerini geride bırakarak en çok tercih edilen alışveriş sitesi olması ve yabancı yatırımları çekerek hem marka değerine hem de ülke ekonomisine katkı yapmasında kullanılan sanal pazarlama stratejilerinin etkisi büyük olmaktadır. Markafoni tarafından etkin ve yaratıcı bir şekilde kullanılan sanal pazarlama stratejilerinin başında ise SEO, sosyal medya ve e-posta pazarlamaları gelmektedir.

İnternet kullanımının ülkemizde hızı bir şekilde artması sonucu SEO çalışmaları e- ticaret firmaları ve girişimlerinin yoğun olarak kullandığı, en çok yatırım yapılan stratejilerden biri haline gelmiştir. Markafoni'nin de en önemli kanalını başarılı bir SEO çalışması doğrultusunda kurgulanmış, kullanıc dostu ve görselliği ön planda olan web sitesi oluşturuyor. Alexa verilerine göre Markafoni'nin web sitesi Türkiye en çok ziyaret edilen sayfalar arasında 157.sırada bulunuyor. Marka görünürlülüğü arttırmasının yanı sıra, reklam maliyetlerinden de önemli tasarruf sağlayan SEO'yu en etkin kullanan girişimlerin başında Markafoni gelmektedir. Nitekim 2016 verilerini değerlendiren Markafoni, AdWords odaklı yeniden hedefleme kampanyasıyla marka dışı reklam harcamalarından elde ettiği geliri yüzde 352 oranında arttırdığını duyurmuştur.

2016 yılında hayata geçirilen SEO stratejisi ile 7 milyon müşterisine ait verileri kullanan Markafoni, ilk olarak CRM segmentlerini Google Analytics 360'a aktarmış bu sayede hedef kitlelere ait yeni dinamikleri belirleyerek farklı segmentlere özel SEO stratejisi geliştirmiştir. Artan reklam tasarruflarının yanı sıra, marka dışı arama sonuçlarında tıklanma oranı \%49 olarak artmış ve önemli geri dönüşüm oranları elde edilmiştir. Kullanılan strateji sonucu marka dışı dönüşüm oranında ise \%986 oranında bir artış gözlemlenmiştir. Uygulanan başarılı stratejilerin bir sonucu olarak Markafoni'nin arama motorlarındaki organik görünürlülüğü rakiplerinin üstündedir.

Markafoni SEO çalışmasının yanı sıra sosyal medya üzerinden yürütülen pazarlama faaliyetlerinde önem veren bir girişimdir. Gelenekselleşen "Yarın Markafoni'de " içerikleri ile kullanıcılar gelecek kampanyalardan haberdar edilmektedir. Sosyal medya kullanımının en yoğun olduğu saatlerde paylaşılan bu postlar site trafiğini arttırarak tüketicilerin alışveriş oranlarını arttırmayı hedefliyor. Markafoni'nin özellikle Facebook'ta önem verdiği detaylardan biri de tüketicilerle etkileşimi sağlamak ve yeni kullanıcıları siteye çekmek. Bu amaç doğrultusunda belirli zaman aralıklarını kapsayan sanal yarışmalarla hem mevcut kullanıı kitlesiyle hem de potansiyel kullanıcılarla yaratıcı bir şekilde iletişim kuruluyor. Facebook için özel olarak hazırlanan ve her gün güncellenen görseller ise kullanıcıların markayı daha kolay takip etmelerini ve alışveriş eğilimlerinin artmasını kolaylaştırmaktadır.

Markafoni'nin daha çok müşteri çekme ve satış oranlarını arttırma amacıyla internet üzerinden gerçekleştirdiği bir diğer strateji de farklı markalarla yapılan işbirlikleridir. Farklı iş modelleriyle hizmet veren diğer e-ticaret siteleri veya bankalarla birlikte gerçekleştirilen kampanyalar doğrultusunda, tüketiciler Markafoni'den indirim çekleri, bedava kargo çeki gibi promosyonlar kazanabilmektedir. Bu çekleri kullanmak için belirli bir alışveriş limitinin var olması ise site üzerinden yapılan alışveriş miktarlarını arttırmayı hedeflemektedir. Ayrıca bu tarz işbirlikleri sayesinde anlaşmalı firmanın web sitesi üzerinden de Markafoni'nin görünürlülüğü artmaktadır.

\section{Markafoni'nin Pazarlama Stratejilerinin Ekonomiye Etkisi}

Tüketicilere sunduğu farklı alışveriş deneyimi ve tedarik-dağıtım sürecindeki başarısıyla kısa sürede hızla büyüyen Markafoni, 2010 yılında TechCrunch tarafından Avrupa'nın en iyi 100 teknoloji şirketi arasında gösterilmiş, 2010 yılı cirolarına göre Avrupa'nın en büyük 300 online perakendecisi listesinde 95.243 .237 dolarlık cirosu ve yüzde $771,52^{\prime}$ lik büyüme oranı ile 111. sırada yer almış, (http://eticaretmag.com), ardından yabancı yatırımların ilgisini çekerek global bir marka olma yolunda önemli mesafeler katetmiştir (http://superbrandsturkey.com). 2011'de hisselerinin yüzde 70'e yakınının 129 ülkede faaliyet gösteren Naspers'a bağı MıH-Allegro tarafından satın alınması Markafoni'nin global bir marka olma sürecinin hızlanması açısından önemli bir gelişme olmuştur. 2015 yılı itibariyle Markafoni 600'ün üzerinde çalışana istihdam sağlamaktadır. Buna ek olarak Markafoni açtı̆̆ı fiziki mağazalarıyla Türkiye'deki offline perakende dünyasına yeni bir soluk getirmiştir. Alışverişçiler artık Markafoni'nin fiziki mağazasında online sipariş verebiliyor, online 
sipariş verdiği ürünleri ise mağazadan teslim alıp iade ya da değişim yapabiliyorlar. Markafoni'nin Zorlu AVM, Ataşehir Novada, İdealtepe sahil yolu ve Uniq İstanbul olmak üzere dört mağaza açtığı da göz önünde bulundurulduğunda istihdam sayılarında artış olduğu görülmektedir. Depo, lojistik, yazılım uzmanlarının yanı sıra şirkette prodüksiyon departmanında ciddi çalışan sayısı bulunmaktadır. Dinamik olarak ürünlerin değiştiği sitede manken, makyöz ve fotoğrafçı gibi dışarıdan çalışanlar da mevcuttur. 7,2 milyon üyesiyle Markafoni, ayda 21,6 milyon ziyaretçi ve 6,2 milyon tekil ziyaretçi almaktadır. Sitede ayda 500'ün üzerinde kampanya düzenlenmekte ve ayda 1 milyonun üzerinde ürün satılmaktadır. Markafoni, Türk internet dünyasının en modern ve en büyük merkezlerinden birinde hizmet vermektedir. 25 bin metrekarelik lojistik merkezi ile günlük gönderim kapasitesi 70 bin pakettir.

\subsection{Tüketici Açisindan Bulgular ve Tartışma}

Sanal pazarlama stratejilerini tüketici gözünden değerlendirmek, e-ticaret girişimlerinin tüketim alışkanlıklarına etkisini değerlendirmek amacıyla 524 kişinin katıldığı bir anket çalışması gerçekleştirilmiştir. Tüketiciler üzerinden pazarlama stratejilerinin değerlendirilmesi çalışmanın tamamlayıcılığı açısından son derece önemlidir. Şirketler tarafından uygulnana pazarlama stratejilerinin de etkinliğinin test edilmesine olanak sağlar. Verilen cevaplar doğrultusunda sanal pazarlama stratejilerinin tüketicilerde satın alma tercihlerini ve oranını etkileyerek, ülke ekonomisi açısından bir hareketlilik yaratıp yaratmadığını; ulusal pazara bir ivme getirip getirmediğinin incelenmesi amaçlanmıştır. Araştırmaya kaynaklık yapan veriler, çevrimiçi anket formu kullanılarak toplanmıştır. Anket çalışmasına katılan bireylerin eğitim düzeyleri yüksek, genç kesim ve belirttikleri aylık kazançlar, \% 51'inin 1000 TL altı, \% 26'sı da 1000-2000 TL arasındadır. Ankete katılanlar, Türkiye'deki internet kullanıcısı özellikleri ile paralellik arzetmektedir. Internet kullanıcı oranının bölgesel farklııkları yansıtacak şekilde katılımcı çeşitliliği içermemekle birlikte, söz konusu bireylerin çevrimiçi alışverişi yoğun olarak kullanmaları; pazarlama stratejilerinin ve internet girişimlerinin e- ticarete ve tüketim oranlarına/tercihlerine etkisini inceleyebilmek açısından önemlidir. Anket formunun hazırlanma aşamasında, e-ticaret alanında tüketici eğilimlerini inceleyen çeşitli çalışmalardan faydalanılmıştır. Buradan hareketle ankete temel oluşturacak 13 soru belirlenmiştir. IIlk dört soru katıımcıların cinsiyet, yaş, eğitim ve gelir bilgilerini ölçmeye yöneliktir. Formda yer alan diğer sorular ise katılımcıların çevrimiçi alışveriş sıklıklarını, çevrimiçi alışverişte göz önünde bulundurdukları kriterleri, sanal pazarlama stratejilerine karşı tepkilerini ve en çok tercih ettikleri internet girişimlerini incelemeye yöneliktir.

Anket çalışmasına katılanların cinsiyet, yaş, eğitim düzeyi ve gelir bilgileri aşağıdaki tablolarda özetlenmiştir(Tablo 2,3 ve 4).

Tablo 2: Ankete Katılanların Cinsiyete Göre Dağılımı

\begin{tabular}{|c|c|c|c|c|c|}
\hline \multicolumn{2}{|c|}{ KADIN } & \multicolumn{2}{c|}{ ERKEK } & \multicolumn{2}{c|}{ TOPLAM } \\
\hline$\%$ & SAYI & $\%$ & SAYI & $\%$ & 524 \\
\hline 50.3 & 264 & 49.6 & 260 & 100 & 524 \\
\hline
\end{tabular}

Tablo 3: Ankete Katılanların Yaşa Göre Dağııımı

\begin{tabular}{|l|l|l|}
\hline YAŞ & \% & SAYI \\
\hline $18-24$ & 74.91 & 400 \\
\hline $25-34$ & 18.91 & 101 \\
\hline $35-44$ & 2.43 & 13 \\
\hline $44+$ & 0.94 & 5 \\
\hline DiĞER & 0.94 & 5 \\
\hline
\end{tabular}

Tablo 4: Ankete Katılanların Eğitim Düzeyine Göre Dağılımı

\begin{tabular}{|l|l|c|}
\hline EĞiTiM & \% & SAYI \\
\hline ILKÖĞRETIM & 0.56 & 3 \\
\hline LISE & 6.18 & 33 \\
\hline ÜNIVERSITE & 78.28 & 418 \\
\hline MESLEK YÜKSEK OKULU & 3.82 & 20 \\
\hline YÜKSEK LISANS/DOKTORA & 8.21 & 43 \\
\hline DiĞER & 1.34 & 7 \\
\hline
\end{tabular}


Tablo 5: Ankete Katılanların Gelire Göre Dağılımı

\begin{tabular}{|l|l|l|}
\hline GELIR & \% & SAYI \\
\hline 1000 TL'DEN AZ & 51.72 & 271 \\
\hline $1000-2000$ TL & 26.72 & 140 \\
\hline $2001-3000$ TL & 7.63 & 40 \\
\hline $3001-5000$ TL & 5.73 & 30 \\
\hline 5000 TL ÜZERi & 4.01 & 21 \\
\hline DiĞER & 4.20 & 22 \\
\hline
\end{tabular}

Kullanım Sıkığı: Katılımcıların çevrimiçi alışveriş yapma oranının belirlenmesi amacıyla "İnternet üzerinden alışveriş yapma sıklığınız nedir?" sorusu yöneltilmiştir. Anket çalışmasına katılan 188 kullanıcı yılda 3-4 kez internet üzerinden alışveriş yaptığını belirtmiştir. 133 kişi yılda bir-iki kez internet üzerinden alışverişi tercih ettiğini belirtirken, 98 kişi bu oranı ayda bir, 75 kişi ise ayda bir kereden fazla olarak belirtmiştir. Anket katılımcılarının ortalama yaş oranının oldukça genç oluşu dikkate alındığında, gençlerin elektronik ticarete adapte olduğunu ve internet üzerinden alışverişin yüksek oranlarla tercih edildiği gözlenmiştir. Kullanıcıların büyük çoğunluğunun aktif olarak internet üzerinden alışverişi kullanmaları, e-ticaretin ekonomiye olan katkısını göstermektedir.

Ankete katılan kullanıcıların \%90'ın üzerinde bir oranla yılda minimum 1-2 kez çevrimiçi alışveriş yaptıklarını belirtmeleri diğer sorulara verilen cevapların yorumlanması açısından önem teşkil etmektedir. Katılımcıların e-ticarete adapte olmuş tüketicilerden oluşması sanal pazarlama stratejilerinin etkinliğinin sorgulanacağı soruların anlamlı bir veri olarak yorumlanabilmesine olanak vermiştir.

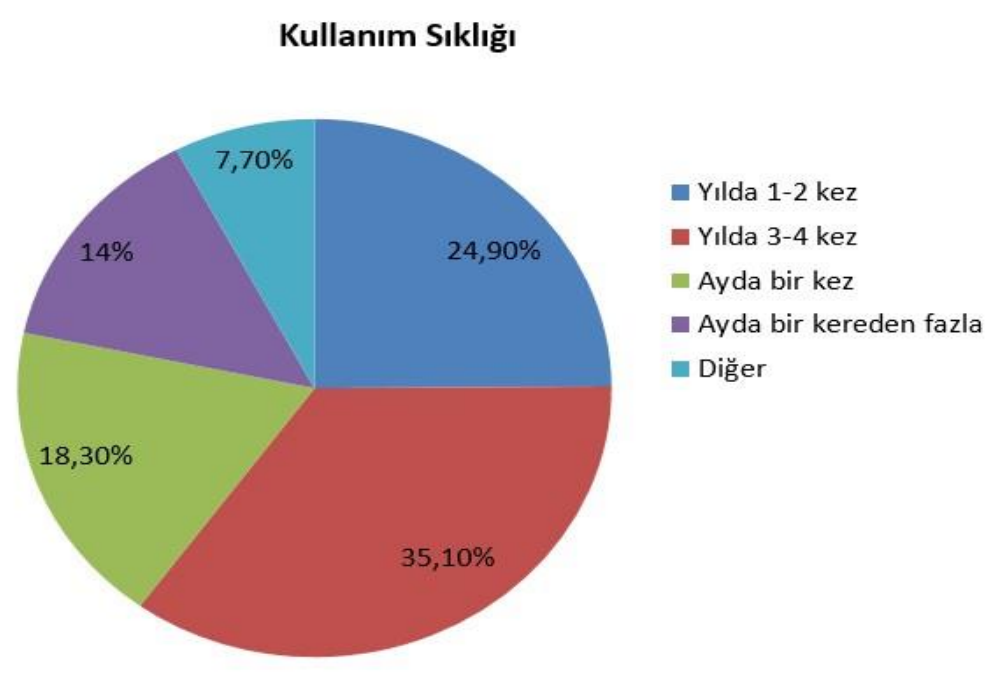

Kanallar: Elektronik ticarette başarılı pazarlama stratejileri uygulamanın formülü doğru tüketiciye en etkin olarak ulaşılabilecek kanalın belirlenmesi ve seçilmesinden geçmektedir. Sosyal medya platformları, web siteleri bu kanallar içerisinde en çok öne çıkanlardır. Sanal pazarlama stratejilerinin tüketicilerin çevrimiçi alışveriş tercihlerinde ve alışkanlıklarında nasıl değişimlere yol açtığı ve e-ticarete teşvik açısından ne derece belirleyici olduğu sorusuna cevap verebilmek amacıyla katıımcılara çevrimiçi alışverişlerinde en sık kullandıkları kanallar sorulmuştur. Alışveriş yaptığınız eticaret sitelerine genellikle hangisi aracılığıyla ulaşırsınız? sorusuna verilen cevaplar, anket sonucunda elde edilen en şaşırtıcı verilerden birini oluşturmaktadır. 524 katılımıının yarısından fazlası normalde tercih ettikleri marka ve mağazaların internet sitesi aracılı̆̆ıla çevrimiçi alışverişlerini gerçekleştirdiklerini belirtmişlerdir. 108 kullanıı ise arkadaş tavsiyesinin çevrimiçi alışverişte marka/site tercihlerinde belirleyici olduğunu ifade etmiştir. Bu durum elektronik ticarette müşterilerin tercihlerini belirleme noktasında arkadaş tavsiyesi, marka sadakati gibi geleneksel bileşenlerin hala belirleyici olduğunu göstermektedir. Bu kanalları sosyal medya ve internet sitelerindeki reklamlarının takip etmesi e-ticaret hacmi üzerinde pazarlama stratejilerinin önemini ortaya koymaktadır. Özellikle seo çalışmaları ve sosyal medya pazarlaması tüketicilerin tercihlerinde önemli bir yere sahiptir. 


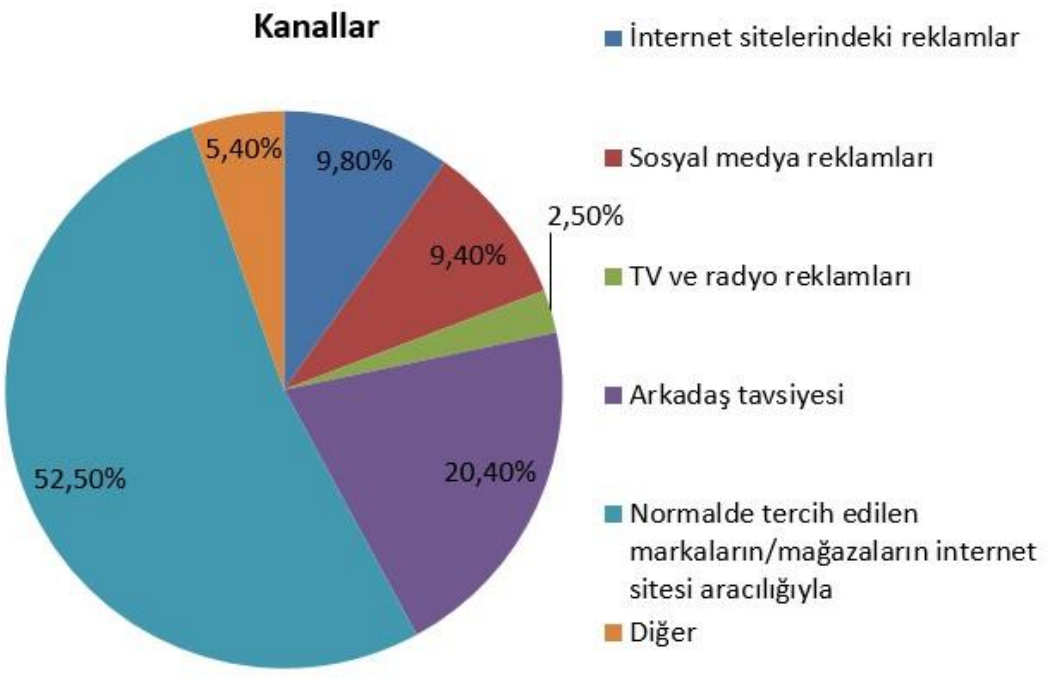

Firma/Girişim Tercihleri: İndirim/fırsat siteleri ve toplu pazaryeri hizmeti sunan e- ticaret girişimi Türkiye'de e-ticaret ekosisteminin gelişimi açısından olumlu ve stratejik bir öneme sahiptir. Sayıları günden güne artan e-ticaret girişimleri, mevcut pazar ortamına yenilikçi dinamikler getirirken tüketicilere de farklı seçenekler sunarak hem makro hem mikro anlamda ülke ekonomisine katkıda bulunmuşlardır. Tüketicilerin kısa bir zaman önce tanıştığı bu siteleri kullanım oranını belirleyebilmek amacıyla "Indirim/fırsat ve toplu pazaryeri hizmeti sunan e-ticaret sitelerini kullanıyor musunuz? (hepsiburada, markafoni, şehirfırsatı, grupfoni, gittigidiyor vb. siteler)" sorusu yöneltilmiştir. Katılımcıların \%77,8 gibi büyük bir bölümü bu tarz siteleri kullandıklarını belirtirken, \%20'si olumsuz cevap vermişlerdir.

\begin{tabular}{|c|c|c|c|c|c|}
\hline \multicolumn{2}{|c|}{ EVET } & HAYIR & \multicolumn{2}{c|}{ DIĞER } \\
\hline$\%$ & SAYI & $\%$ & SAYI & $\%$ & SAYI \\
\hline 77,8 & 417 & 20 & 107 & 2,2 & 12 \\
\hline
\end{tabular}

Bir diğer soruda ise katılımcılardan en çok tercih ettikleri elektronik ticaret sitesini işaretlemeleri istenmiştir. Anket formuna yerleştirilen seçenekler Türkiye'nin en çok tercih edilen/en popüler internet girişimlerinden oluşmaktadır: Markafoni, Gittigidiyor, Hepsiburada, Sahibinden, Yemeksepeti, Grupanya, Şehir Fırsatı, İdefix/Kitap Yurdu, Biletix, Diğerleri. 
Tüketim İsteği/Tüketime Teşvik

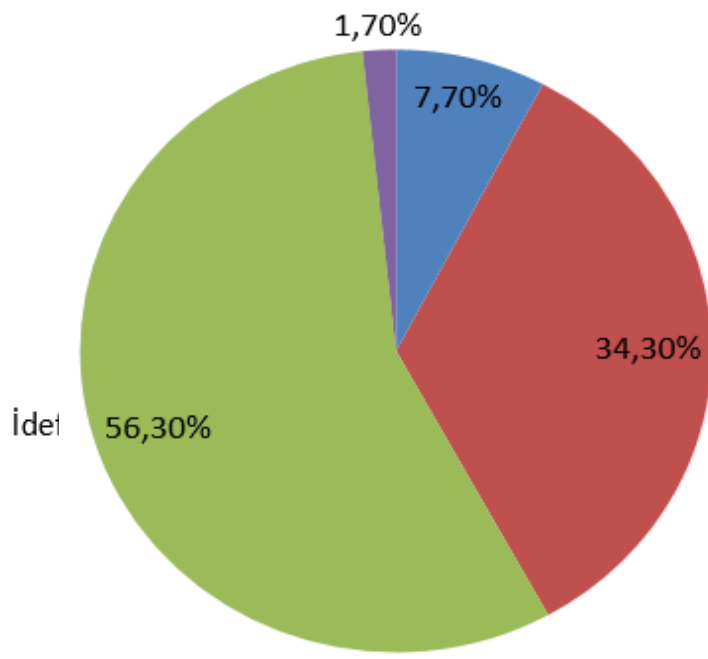

Evet, genellikle sonradan ihtiyacım olmadığını farkettiğim ürünler satın alıyorum.

a Bazen oluyor.

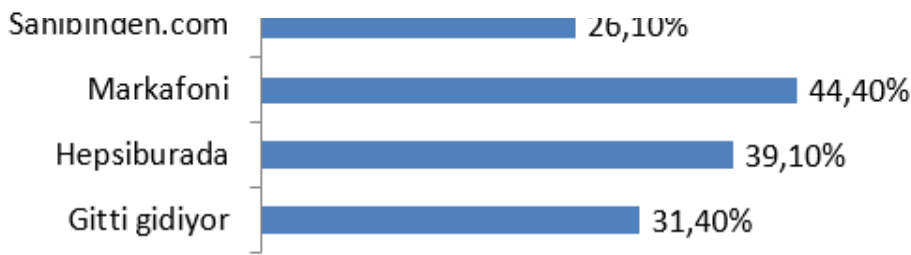

Hayır, ihtiyacım olan ürünleri satın alıyorum.

Diğer

Bu aşamada katılımcıların birden fazla siteyi işaretleyebilmelerine imkan verilmiştir. 524 katılımcının verdiği cevaplar doğrultusunda Yemeksepeti ve Markafoni'nin en çok tercih edilen elektronik ticaret siteleri olduğu görülmektedir. 236 kişi Markafoni'den alışveriş yaptığını belirtirken 251 kişi Yemeksepeti'ni kullandığını belirtmiştir. Bu durum yemeksepti.com ve Markafoni'nin pazarlama stratejilerini etkin kullandığını gösteren önemli bir sonuçtur. Anket verilerinde dikkat çeken bir diğer nokta, şehir fırsatı, grupanya gibi özel alışveriş kulüplerinin yoğun olarak tercih edildiğini ortaya koymaktadır.

Tüketim Isteği/Tüketime Teşvik: Çalışmanın önceki bölümlerinde e-ticaretin farklı iş modelleri geliştirerek ve pazara farklı ürünler sunup yaratıcı bir biçimde pazarlayarak tüketimi arttırdığına değinilmiş ve bu görüş çeșitli çalışmalarla ve raporlarla desteklenmiştir. Anket çalışması kapsamında bu olgu da incelenmeye çalışılmıştır. "Internet sitelerinde veya sosyal medyada gezinirken karşılaştığınız veya maille haberdar olduğunuz indirim ve promosyonlar doğrultusunda alışveriş yaptığınız oluyor mu?" sorusuna katılımcılar tarafından verilen cevaplar sanal pazarlama stratejilerinin tüketicileri alışverişe teşvik ettiğini doğrulamaktadır. 524 kişinin verdiği cevaplar doğrultusunda sosyal medyada veya e-mail pazarlaması aracılığıyla sunulan fırsat ve indirimlerin katılımcıların \%53,9'unu çevrimiçi alışverişe yönelttiği görülmektedir. Bunun sonucunda e-ticarette uzun zamandır kullanılan e-posta pazarlamasında gönderilen e-postanın içeriği ve zamanlamanın doğru ve cezbedici olduğunda tüketicileri online alışverişe yönelttiği görülmektedir. Ayrıca bu soruyla sosyal medya pazarlamasının tüketicilerin tercihlerinde önemli bir yere sahip olduğu önceki soruda olduğu gibi tekrar gözler önüne serilmektedir.

\begin{tabular}{|c|c|c|c|c|c|}
\hline \multicolumn{2}{|c|}{ EVET } & HAYIR & \multicolumn{2}{c|}{ DIĞER } \\
\hline$\%$ & SAYI & $\%$ & SAYI & $\%$ & SAYI \\
\hline 53,9 & 286 & 41,1 & 218 & 5,1 & 27 \\
\hline
\end{tabular}

Anket formunda yer alan bir diğer soruyla fırsat ve indirim sitelerinin tüketicileri alışverişe teşvik etmede nasıl bir işlev üstlendiği sorusuna cevap aranmıştır. Bu amaçla katılımcılara "Fırsat ve indirim sitelerinden alışveriş yaparken daha sonra ihtiyacınız olmadığını farkettiğiniz bir ürün aldığınız oldu mu?" sorusu yöneltilmiştir. 41 kişi genellikle ihtiyacı olmadığı ürünleri aldığını belirtirken, 183 kişi bazen ihtiyaç hissetmediği ürünler için alışveriş yaptığını ifade etmiştir.

Ürün/Sektör Tercihleri: Elektronik ticaret, beraberinde getirdiği yeni iş modelleri ve sanal pazarlama stratejileri belirli ürün ve hizmetlerin tüketicilere ulaştırımasını kolaylaştırmakta, dolayısıyla sektörel anlamda ülke ekonomisine katkıda bulunmakta ve rekabet ortamına hareketlilik getirmektedir. Tüketicilerin çevrimiçi alışverişle satın almayı tercih ettiği ürün ve hizmet grupları e-ticaret'in teşvik ettiği sektörel değişimleri ve e-ticaretin tüketim artışına etkisini anlama noktasında da ipuçları vermektedir. Bu ilişkiyi değerlendirebilmek amacıyla katılımcılara "Internetten alışveriş yapmaya başladığınızdan beri belirli ürün veya hizmetleri tüketim sıklığınız arttı mı? Arttıysa bu ürün ve hizmetler en çok hangi kategoriyi kapsıyor?" 
sorusu yöneltilmiştir. 193 katılımcl; uçak, otobüs, sinema, tiyatro, konser, workshop vb. hizmetlerden daha fazla yararlandıkları daha sık bilet aldıklarını belirtirken,103 kişi giyim seçeneğini işaretlemiştir. Tüketici bakış açısıyla, e-ticaretin yaygınlaşmasıyla tüketicileri daha çok etkinliğe katılma şansı elde edebilmektedir. Bu veriler de e-ticaretin etkinlik ve eğlence sektörüne önemli katkısı olduğunu göstermektedir.

Ürün/hizmet tercihlerine ilişkin katılımcılara yöneltilen bir diğer soru "İnternet üzerinden aldığınız ürünlere ilişkin en önemli kriteriniz nedir?" şeklindedir. Katılımcıların cevapları doğrultusunda elde edilen veriler çevrimiçi alışverişte en belirleyici kriterin fiyat olduğunu göstermektedir. 280 kişi fiyatın en önemli kriter olduğunu belirtirken, 102 kişi ürün ve hizmet kalitesinin tercihlerini belirlediğini ifade etmiştir. Bu soru kapsamında elde edilen en önemli verilerden biri; satın alma sonrası verilen müşteri hizmetlerinin, ürünlerin çeşitliliği kriteriyle benzer oranlarda belirleyici oluşudur. 50 katılımcı çevrimiçi alışverişte en önemli kriterlerinin özgünlük/çeşitlilik olduğunu belirtmiş, 49 katılımcı ise satın alma sonrası verilen müşteri hizmetleri seçeneğini işaretlemiştir.

Küresel Elektronik Ticaret: İnternet aracılığı ile yurtdışından alışveriş yaptınız mı? (e- bay, amazon, alibaba vb.siteler) Anket katılımcılarının yurtdışından alışveriş yapma oranı gelişmiş ülkelerde gözlemlenen oranlarla büyük bir benzerlik içerisindedir. Örneğin Avrupa Komisyonu'nun yaptığı çalışmaya göre Avrupa Birliği'ne üye ülkelerin vatandaşlarının kendi ülkeleri dışında bir ülkeden online satın alma oranı \%52 olarak belirtilmektedir (http://ec.europa.eu) Anket katılımcılarının verdiği cevaplara göre ise bu oran çalışmanın örnekleminde \%48.6 olarak ölçülmüştür. Çalışmanın elde ettiği bu veri, genç tüketicilerin global anlamda da çevrimiçi alışverişi deneyimlediğini ortaya koymaktadır.

\begin{tabular}{|c|c|c|c|c|c|}
\hline \multicolumn{2}{|c|}{ EVET } & HAYIR & \multicolumn{2}{c|}{ DiĞER } \\
\hline$\%$ & SAYI & $\%$ & SAYI & $\%$ & SAYI \\
\hline 48,6 & 260 & 49,9 & 267 & 1,5 & 8 \\
\hline
\end{tabular}

\section{SONUÇ}

20.yüzyııı sonlarından itibaren gerçekleşmeye başlayan ilerlemeler, internetin bireysel kullanımının yaygınlaşması geleneksel ticaretin yönünü değiştirmiş; elektronik ticaret yeni ekonominin temel dinamiklerinden biri haline gelerek gelişmiş ve geliş̧mekte olan ülkelerde faaliyet gösteren her ölçekte firma için önemli fırsatları beraberinde getirmiştir. Söz konusu fırsatları değerlendirme hedefiyle pazara yeni ve dinamik iş modelleri sunan internet girişimleri ise sayılarını günden güne arttırarak hem e-ticaret ekosistemi hem de ülkelerin gayri safi milli hasılalarını olumlu yönde etkileyerek ticari faaliyetlerinin ağlar üzerinden gerçekleştiği, rekabetin yoğun olduğu, tüketici odaklı yeni pazar yapısının temelini oluşturmuştur. Üretim faktörleri, pazarlama yöntemleri, lojistik faaliyetleri ve sektörel dinamiklerin yanı sıra, tüketici beklenti ve davranışlarını da köklü bir biçimde etkileyen ve dönüştüren e-ticaret'in ulusal ekonomilere en büyük etkisi; zaman, mekan ve yatırıma dayalı engellerin ortadan kalkmasıyla gerçekleşmektedir ( http://inet-tr.org.tr).

Söz konusu engellerin kalkması ve e-ticaret'in günümüz itibariyle ulaştı̆̆ı boyut ve potansiyelde, bilgi ve iletişim teknolojilerinde gerçekleşen radikal değişimler belirleyici olmuş, bütün ekonomik birimlerin adaptasyonu ile ekonomik yapı çok katmanlı ve öngörülmesi zor bir şekilde dinamik ve karmaşık bir yapıya doğru evrilmiştir. Ulusal ekonomiler açısından bakıldığında ise, söz konusu değişimlerin ülkenin üretim, tüketim ve dağıtım faktörlerine hangi derecede uyarlandığına, bir diğer deyişle, ülkelerin bilgi ve iletişim teknolojilerinin getirdiği yenilik ve imkanları kendi dinamikleriyle ne ölçüde yakınsadıklarına bağlı olarak e-ticaret’ten alınan verimin oranı değişmektedir (Ovalı, 2014).

Türkiye'de, geçmiş yıllarda büyük ilerlemeler kaydetmiş ekonomisi, genç ve dinamik nüfus avantajı, lojistik açısından coğrafi olarak ayrıcalıklı konumu, Asya-Pasifik gibi önemli pazarlara yakınlığı, Avrupa Birliği'ne aday ülke olarak sahip olduğu birtakım ayrıcalık ve fonlar, girişimcilik ruhu ve çeşitli kaynakları sayesinde küresel e-ticaretin kalkındırıcı ve geliştirici etkisinden her geçen gün artan bir hızla faydalanmaktadır. BiT teknolojileri ve küresel gelişmelerin yanı sıra, hukuki mevzuata ilişkin düzenlemeler, teşvik edici program ve ulusal stratejilerinin de katkısıyla e-ticaret'in Türkiye ekonomisine ilişkin olumlu etkileri; hem makro-ekonomik hem de mikro-ekonomik düzeyde gerçekleşmekte; verimlilik ve üretim, fiyatlar, istihdam, ihracat ve yatırımların yanı sıra sektörel düzeyde de önemli ilerlemeler gerçekleştirilmektedir.

Literatür taraması ve anket çalışması sonucunda elde edilen verilerin ışı̆̆ında dünyada ve Türkiye'de e-ticaretin hacmi ve potansiyelinin yanı sıra; sanal pazarlama stratejilerinin istihdama, tüketime, pazar yapısına yabancı yatırımlara; dolayısıyla Türkiye ekonomisine olumlu etkileri çeşitli başlıklar altında toplanmıştır. Mevcut bulgular ve çalışmanın altını çizdiği dinamikler şu şekilde özetlenebilir:

E-ticaret'in Türkiye ekonomisine istihdam, fiyat, rekabet gibi noktalarda yaptığı katkıların yanı sıra; dış yatırımlar ve ihracatın gelişmesi de e-ticaret'in yaygınlaşmasıyla hız kazanmıştır. Dünyanın önde gelen e-ticaret firmaları ve yatırım fonlarının, potansiyeli yüksek, başarılı internet girişimlerine yaptıkları yatırımlar Türkiye'nin e-ticaret potansiyelini 
arttırken, diğer girişimler için de teşvik edici bir unsur olmakta ve global yatırımların ülkeye girişini hızlandırmaktadır. Ticari anlamda küreselleşme adına da itici bir gücü ifade eden bu ortaklık ve yatırımlar, Türkiye'nin e-ticaret hizmetlerinde uluslararası standartları yakalaması noktasında da önemli olmaktadır.

Özellikle geleneksel anlamda ihracat yapma imkanı olmayan orta ve küçük ölçekli işletmelerin e-ticaret sayesinde ihracat yapabiliyor duruma gelmiş olması, Türkiye'nin ihracat menzilini arttırarak bir başka açıdan Türk ekonomisine olumlu etkilerde bulunmaktadır. E- ticaretin sunduğu avanvajlar sayesinde rekabet gücümüzün az olduğu bazı okyanus aşırı pazarlarda Türk firmalarının ticaret kapasitesi artmıştır. Bu avantajlar, Türkiye'nin ihracat potansiyelini tam olarak gösterememesinin altında yatılan sorunlar gözönünde bulundurularak değerlendirildiğinde elektronik ihracatın sunduğu fırsatlar daha da belirginleşmektedir. Örneğin; Türkiye'nin geleneksel anlamda en fazla ihracat yaptığı ürün gubunu motorlu kara taşıtları oluşturmaktadır(www.tepav.org). Bu ürünlerin hacimsel olarak uluslararası pazarlara iletilmesi daha zor olmakta, lojistik maaliyetlerinin çok fazla olması Türkiye'nin bu alandaki rekabet gücünü olumsuz olarak etkilemektedir. Buna karşılık Türkiye'nin e-ihracatını, lojistik açıdan pazarlanması daha kolay, mesafe farklarından daha az etkilenen ürünler oluşturmaktadır. Türkiye'nin ucuz üretim avantajını kullanabileceği ve okyanus aşırı pazarlara çok rahat ulaştırabileceği bu ürünler, büyük firmaların yanı sıra küçük ve orta ölçekli firmaların da e-ihracattan aldığı payı da büyük oranda arttırmıştır (Aslan, 2006).

Türkiye'de e-ticaret kullanımı pozitif bir ivme içerisinde, farklı sektörleri kapsayacak şekilde artış içerisindedir. Genç nüfusun çevrimiçi alışverişe adaptasyonu gelişmiş ülkelerdeki oranlara çok yakındır. Tüketicilerin yeni girişimleri tercih etme oranının yüksek olması ve anket sonuçlarının da işaret ettiği üzere belirli ürün kategorilerinde, çevrimiçi alışverişin geleneksel alışveriş yöntemlerine tercih edilmesi internet girişimlerinin önünü açarak Türk ekonomisine katkı sağlamaktadır. Bu katkının en önemli unsurlarından biri de istihdamdır. Üretici, tüketici ve tedarikçilerin açık ağ üzerinde bir araya gelmesi elektronik faaliyetleri elektronik ortama taşıması sonucu istihdam edilen işgücünün yapısında da önemli değişimler meydana gelmektedir. Elektronik ticaretin ülke içerisindeki istihdam ve işgücü üzerindeki olumlu ve olumsuz etkilerini direkt olarak ölçümleyebilmenin mümkün olmamasıyla birlikte, istihdam edilen işgücünün yapısı, niteliği ve sayısında yaşanan bu değişim, hem firmalar hem de çalışanlar açısından hissedilebilir durumdadır (Sam ve Heerden, 2003). Geleneksel ticaretten farklı olarak gerçekleşen iş süreçleri ve pazar yapısındaki farklılaşma, belirli meslek kollarının önemini azaltırken; yeni meslek kollarının da önemini artırmaktadır.

Ortaya çıkan yeni meslekler ve değerlenen sektörlerle birlikte Türkiye'de yeni çalışma alanları gelişmekte ve bu durum istihdamın niteliği ve niceliğine doğudan etki yapmaktadır. Örneğin; istihdam yapısını ve verimliliğini geliştirebilmek amacıyla Türkiye'de bilgi ve iletişim teknolojileri alanında yetişmiş, uluslararası pazarda rekabet gücü kazandıracak istihdamın yaratılmasına ilişkin politikalar ilk olarak Beşinci Kalkınma Planı'nda yer almıştır (www.bilgitoplumu.gov.tr) .Bu alanda yaratılacak nitelikli işgücünün hem ulusal pazarda hem de küresel rekabet ortamında Türk ekonomisine yapacağı katkıların anlaşılmasının ardından, BiT sektörüne yapılan yatırımlarda düzenli artışlar meydana gelmiştir. BTK verilerine göre, 2015 yılı itibariyle bu alanda istihdam edilen kişi sayısı 113.000'e ulaşmıştır (www2.deloitte.com). Türkiye'de eticaret ile birlikte gelişme gösteren yeni meslek gruplarında büyük bir istihdam açığı bulunmaktadır. "íhracat Stratejisi ve Eylem Planı" kapsamında 2023 yılı yılına kadar 1 milyonluk bir IT istihdamı ve 10 milyar \$'lık IT sektör büyüklüg̈ü hedefleyen Türkiye'nin bu rakamlara ulaşması için uzun bir yolu olmasına karşın, gerekli adımların atılması sonucu bu işgücü açığını istihdama çevrilmesiyle Türk ekonomisi önemli bir değer elde edecektir (http://geka.gov.tr).

Özel alışveriş kulüpleri, fırsat siteleri ve e-ticaret alanında faaliyet gösteren diğer internet girişimleri tüketimi teşvik noktasında önemli roller üstlenerek hem rekabetçi pazar ortamına hem de ticari faaliyetlerin yoğunluğuna etkide bulunarak ülke ekonomisine katkı sağlamaktadır. Çevrimiçi alışverişte fiyat ve kalite unsurları; tüketici tercihlerini belirlemektedir. Araştırmaya katılan tüketiciler çevrimiçi alışveriş yapmaya başladıklarından beri bilet kategorisinde daha fazla alışveriş yapmaya başladıklarını ifade etmişlerdir. Mevcut kategori uçak ve otobüs biletlerinin yanı sıra; konser, workshop, tiyatro gibi etkinlikler için satışa sunulan biletleri de kapsamaktadır. Bu durum e-ticaret'in kültür-sanat alanında gerçekleşen tüketime olumlu etkilerde bulunduğunun da altını çizmektedir. Elektronik ticaretin, işletme örgütlenmelerini ve işleyişlerini yeniden biçimlendirerek birçok sektör ve firmanın geleneksel yapıları üzerinde önemli değişikliklere yol açmıştır. Tüketiciler geleneksel perakendecilere, toptancılara ve fiziksel varlığı olmayan hizmetleri satın almak için dağıtıcılara gitmek yerine doğrudan üreticilere gitme imkanına kavuşmuş, bu da bazı sektörler üzerinde yıkıcı etkilerde bulunurken, yeni sektörler ve iş kollarının doğması, kendini yenileyebilen sektörlerin ise karlıık ve piyasa hakimiyetlerini arttırmalarıyla sonuçlanmıştır (Çetinkaya, 2017).

E-ticaret'in gelişimi ile birlikte önceden ticari değeri olmayan yeni iş kolları ortaya çıkmıştır. Veri madenciliği, dijital pazarlama ajansları bu iş kollarına örnek verilebilir. Küresel e- ticaretin hız kazanması bazı sektörleri olumlu etkilemesine karşın, iş süreçlerindeki dijitalleşmenin bir getiresi olarak bazı sektörlerin önemini yitirmesine sebep olmuştur. Iletişim kurmaya ilişkin engellerin kalkması, bilginin herkes için ulaşılabilir olması, ticari temaslarda çevrimiçi iletişimin kullanılmaya başlanmasıyla aracı firmalar, seyahat acentalar, geleneksel medya kuruluşları ve ajanslar sektör içerisindeki canlııklarını yitirmeye başlamıştır(Terzi, 2016). 
Sanal pazarlama stratejilerinin satın almayı etkilemedeki kritik rolü hem ilgili araştırmalar hem de e-ticaret firmaları tarafından kabul edilmektedir. Fakat araştırma verileri arkadaş tavsiyesinin çevrimiçi satın alma kararları üzerinde de yoğun etkisi olduğunu ortaya koymaktadır. Bununla birlikte özellikle e-posta ve sosyal medya pazarlamasının tüketici tercihlerine önemli etkisi olduğu ve tüketicileri e-ticarete teşvik ettiği görülmektedir.

Anket bulgularının ışı̆ında e-ticaret girişimlerinin ve sanal pazarlama stratejilerinin tüketici, pazar ve ülke ekonomisi açısından olumlu katkıları tüketime teşvik; ürün, kalite ve fiyatta sunulan çeşitlilik ile pazarlama giderlerinin azalması şeklinde ifade edilebilir. Anket verilerinin de işaret ettiği üzere, e-ticaret'in Türkiye ekonomisine makro-ekonomik anlamda en önemli katkılarının başında verimlilik artışı ve iş süreçlerinin dijitalleşmesiyle gözlenen tasarruflar gelmektedir. Verimlilik ve sürdürülebilir gelişmenin, dünyanın en büyük ekonomilerinin önde gelen gündem maddesi olduğu göz önüne alındığında, verimlilik noktasında gerçekleşen artışın Türkiye ekonomisinin toplam gelirine yaptığı ve yapacağı potansiyel katkılar daha da önem kazanmaktadır (Baydar, 2014). E-ticaret üretime dair süreçlerde aracıları kaldırarak verimlilik sağlamasının yanı sıra; bürokrasi ve kağıt işlerinden de tasarruf etmeyi beraberinde getirmektedir. Dünyadaki en başarı edevlet sistemlerinden birine sahip olan Türkiye'de, ticari işlemlerin büyük bir kısmı artık bir platform aracılığıyla gerçekleştirilmektedir. Kullanımı giderek yaygınlaşan e-dönüşüm uygulamaları sayesinde; hukuki ve ticari işlemlerin yürütülmesinde gözlemlenen artışın yanı sıra, her yıl milyonlarca Türk Lirası tasarruf sağlandığı ifade edilmektedir (www.bilgitoplumu.gov.tr).

E-ticaret girişimlerinin ve sanal pazarlama stratejilerinin başarı potansiyellerini ve pazara, ülke ekonomisine katkılarını sınırlandıran başlıca engeller ise; tüketicilerin fiyat hassasiyeti, arkadaş tavsiyesi gibi satın almada etkili olan geleneksel yönlendirici faktörlerin varlığı ve bazı sektörlerin dijital dönüşümlerini yeterince tamamlayamamaları, yeni iş modelleri sunamamaları nedeniyle çevrimiçi alışverişlerde geri planda kalmaları olarak ifade edilebilir.

Nüfusun yarısından fazlasının internet kullanııısı, genç ve dinamik nüfus yapısı, artan eğitim seviyesi ve gelişmekte olan teknolojik altyapısı ile birlikte Türkiye'nin e-ticaretten aldığı pay her geçen gün artarak hem ulusal hem uluslararası pazarlarda ticaret hacim ve potansiyelini arttırmakta, ülke ekonomisine önemli getirilerde bulunmaktadır. Kamu ve özel sektörde gözlemlenen e-dönüşüm oranları, artan e-ticaret kullanıcı sayısı, yasal ve sektörel düzenlemelere rağmen; e-ticaret potansiyelinin tam olarak değerlendirilemediği, gelişmiş ülkelerin gerisinde kalındığı, bir diğer ifadeyle, Türk ekonomisinin bilgi ve iletişim teknolojilerinin öncülük ettiği radikal dönüşümden azami ölçüde faydalanabilmesi için mevcut değerlerin etkin yönetimine intiyaç olduğu görülmektedir. Bu amaçla atılması gereken adımların başında teknolojik altyapının geliştirilmesi ve standardizasyonun sağlanması gelmektedir. Altyapı noktasındaki belirgin aksaklıkların giderilmesinin yanı sıra; yasal mevzuatın geliştirilmesi, melek yatırımcılara dair düzenlemelerin gözden geçirilerek girişimcilik ekosisteminin canlandırılması, kobilere hali hazırda verilen desteklerin bürokratik süreçlerden arındırılarak daha çok girişimciye ulaştırıması, tekno-parklara yapılan yatırımların arttırılması yeni girişimlerin önünü açarak hem iç pazarı canlandıracak hem de dış yatırımları ülkeye çekerek mikro ve makro ekonomik ilerlemeleri beraberinde getirecek ve Türkiye'nin rekabet gücünü ciddi ölçüde arttıracaktır.

Devlet destekli gerçekleştirilmesi gereken düzenlemeler ve uygulamalara ek olarak, işletmeci ve girişimcilerin üstleneceği roller de e-ticaretten alınan verimin arttırıması adına stratejik önem taşımaktadır. Bu doğrultuda; tüketicilerin beklenti ve istekleri doğru analiz edilmeli, sanal pazarlama stratejileri kapsamlı olarak kurgulanmalı, lojistik süreçler ve müşteri ilişkileri sorunsuz ve hızlı işeleyecek şekilde tasarlanmalı ve geleneksel iş yapısı ve süreçlerinin sanal dönüşümü tamamlanmalıdır. Eticaret'in bir web sitesi üzerinden ürün ve hizmet satmaktan daha karmaşık ve çok değişkenli bir süreç oluşu işletmeleciler ve girişimciler tarafından kavranmalı, geleneksel iş süreçleri ve pazarlama yöntemlerinin e-ticarette uygulanmasından kaçınılmalı, yenilikçi ve müşteri odaklı çözümler benimsenmeli, marka imajı ve mesajının önemi kavranmalı, doğru iletişim kanalları seçilmelidir. Tüm bu önerilere ek olarak; e-ticaret'in gelişiminin önündeki en temel sorunlardan biri olan tüketici kaynaklı güvensizlikler ve algı sorunu giderilmeli, yeni medya okur yazarlı̆ı̆ arttırılarak sadece belirli kesimlerin ve yaş gruplarının değil; her yaştan, her gelir düzeyinden ve her bölgeden tüketicilerin e-ticaret'i benimsemesi ve tercih etmesi hedefiyle gerekli eğitimler verilmeli, kamu spotları oluşturulmalı ve tüketicilerin e-ticaret'in sağladığı fayda ve imkanlardan haberdar olmaları sağlanmalıdır. 


\section{KAYNAKLAR}

Altınışık, I. \& Bilge, F. (2014). Yeni Bin Yıla Girerken Ticaretin Değişen Yüzü: E-Ticaret. Selçuk Üniversitesi Sosyal Bilimler MYO Dergisi, s.2.

Argan M. \& Tokay M (2006), Viral Pazarlama veya İnternet Üzerinde Ağızdan Ağıza Reklam: Kuramsal Bir Çerçeve. Anadolu Üniversitesi Sosyal Bilimler Dergisi, 6(2), s.231

Aslan, Ö. (2006) İnternet Ekonomisi. İstanbul Üniversitesi İletişim Fakültesi Dergisi, (26), 5, s.3.

Başok Yurdakul, N. (2006). Bütünleşik pazarlama iletişimi (ROI) ölçümleme süreci. Ankara : Nobel

Baydar, B. (2014) Bilgi Ekonomisi ve Türkiye, International Conference On Eurasian Economies, s.3

Canpolat, Ö. (2001).E-ticaret ve Türkiye'deki gelişmeler. Ankara: Sanayi ve Ticaret Bakanlığı, s.14

Chopra, S. (2016). How omni-channel can be the future of retailing. Decision (0304-0941), 43(2), s.135-144

Çak, M.(2002). Dünyada ve Türkiye'de Elektronik Ticaret ve Vergilendirilmesi. İstanbul : ITTO.

Çetinkaya, Ş. (2017) E-Ticaret Uygulamalarının Makro Ekonomik Göstergelere Etkisi SWOT Analizi Ve Türkiye’De E-Ticaret Gelişimi Için Bir Eylem Planı Önerisi [e-book]. Yalova Üniversitesi;, s.235-256

Ekin, N.(1998). Bilgi Ekonomisinde E-Ticaret, Istanbul: ITO Yayınları.

Erkan Akar, Sosyal medya pazarlaması : sosyal webde pazarlama stratejileri. İstanbul : Efil Yayınevi, 2011.

France, Tim- YEN, Dave- WANG, Jyun Cheng-CAHNG, Chia Ming. (2002). "Integrating search engines with data mining for customeroriented information search", Information Management\&Computer Security, 10/5, 242-254.

Fulgoni, M. (2014). "Omni-Channel" Retail Insights and The Consumer's Path-to-Purchase. Journal Of Advertising Research, 54(4), s.377-380

Işık, M. (2013). Arama motorları mimarisi, web sayfalarının içerik skoru ve google pagerank formülünün incelenmesi. İstanbul: Kadir Has Üniversitesi, 2013.

Kara, T. (2016). Sosyal Medya'nın Kaldıraç Etkisi: Türk Sivil Havacılık Endüstrisi Sosyal Medya Gücünü Nasıl Kullanıyor ?

The Turkish Online Journal Of Design, Art And Communication, 6(1), 2016, s.62

Kazgan, G. (2002). Küreselleşme ve ulus-devlet, yeni ekonomik düzen ne getiriyor? ne götürüyor? nereye gidiyor?. İstanbul : İstanbul Bilgi Üniv. Yayınları.

Ovalı, S. (2014). "Küresel Rekabet Gücü Açısından Türkiye'nin Konumu Üzerine Bir Değerlendirme”. International Journal Of Economic \& Administrative Studies, 7(13), s.17-36.

Saatçioğlu, C. (2005), Yeni Ekonomi ve Finansal Piyasalar Üzerindeki Etkisi. Atatürk Üniversitesi Iktisadi Ve Idari Bilimler Dergisi, $19(1)$, s.151.

Sam, L. \& Van Heerden, M. (2003) The Economic and Social Impacts of E-commerce. Hershey, PA: IGI Global

Sevindik, T. (2009). The Search Engines Optimization and General Use, NWSA.

Terzi, N. (2016a). The Impact of E-Commerce on International Trade and Employment, Encyclopedia of E-Commerce Development, Implementation and Management, In Lee, IGI Global.

Terzi, N. (2016b). Opportunities and Challenges in Turkey, Encyclopedia of E-Commerce Development, Implementation and Management, In Lee, IGI Global.

Terzi, N (2017). E-Ekonomi, Türkmen Kitabevi, İstanbul.

Todor, R. (2016). Blending traditional and digital marketing. Bulletin Of The Transilvania University Of Brasov, Series I: En gineering Sciences, 9(1), s.51-6

Türen, U. \& Gökmen, Y. \& Tokmak,i. (2011). Türkiye'de e-ticaret işlem hacmini etkileyen faktörler üzerine bir araştırma: Bir model önerisi. Savunma Bilimleri Dergisi, 10(1),s.49.

Ünal, S. (2012). İnternet üzerinde izinli pazarlama yaklaşımı. ÖNERi: Marmara Üniversitesi Sosyal Bilimler Enstitüsü Dergisi, 9(34), s.155

Yurdakul, M. \& Kiracı, H.(2008). Sanal Pazarlama karması Bileşimi. Suleyman Demirel University Journal Of Faculty Of Economics \& Administrative Sciences, 13(2), 2008, s.165-185.

http://www.tuik.gov.tr/PreTablo.do?alt id=1028 (2017, 3 Mart)

http://www.oecd.org/development/electroniccommerce.htm (2016, 5 Haziran)

http://www.mevzuat.gov.tr/MevzuatMetin/1.5.6563.pdf /2016, 28 Mayıs)

https://www.statista.com/statistics/220177/b2c-e-commerce-sales-cagr-forecast-for-selected-countries/ (2017, 27 Şubat)

http://www.kigem.com/bir-fikir-buldu-hayati-degisti.html (2016, 27 Kasım) 
http://www.marketingturkiye.com.tr/haberler/1500-kisiye-istihdam-saglayacak/ ( 2016, 27 Kasım)

http://ec.europa.eu/eurostat/statistics-explained/index.php/E-

commerce_statistics_for_individuals\#32.C2.A0.25_of_online_shoppers_bought_or_ordered_goods_or_service s_from_sellers_in_other_EU_countries $(2017,16$ Ocak)

http://www.superbrandsturkey.com/markalar/Markafoni/markafon-tr.pdf (2017, 7 Şubat)

http://teknolojituru.com/2016/07/29/yemeksepeti-com-un-cirosu-gunluk-siparis-ve-kullanici-sayisi-ne- kadar/ (2017, 7 Şubat)

https://www.statista.com/statistics/534123/e-commerce-share-of-retail-sales-worldwide/ (2016, 8 Haziran)

http://www2.deloitte.com/tr/tr/pages/technology-media-and-telecommunications/articles/turkiyede-eticaret-2014-pazar-buyuklugu.html (2017, 8 Ocak)

http://webrazzi.com/2016/04/06/turkiyede-e-ticaretin-toplam-perakende-icindeki-payi-yuzde-13/ (2017, 8 Ocak) 